

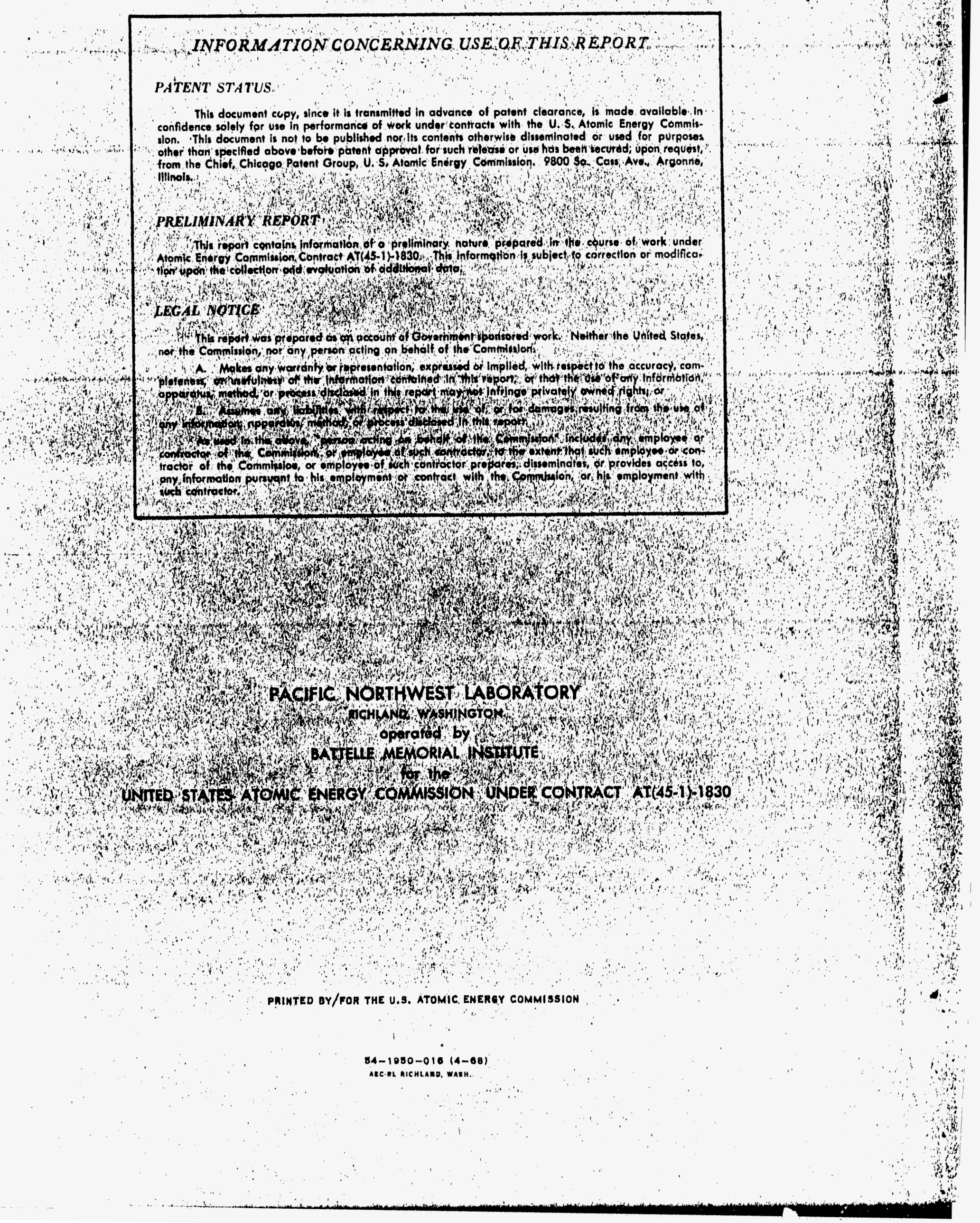


This document consists of 41 pages. Copy NC Nongh

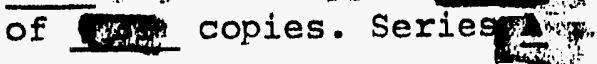

Hanford Category $\mathrm{C}-44 \mathrm{~b}$

\section{COMPOSITION AND RADIOACTIVITY OF REACTOR FILMS}

W. B. Silker

November 18,1968

PATTELIE MEMORIAL INSTITUTE

PACIFIC NORTHWEST LABORATORY

Richland, Washington

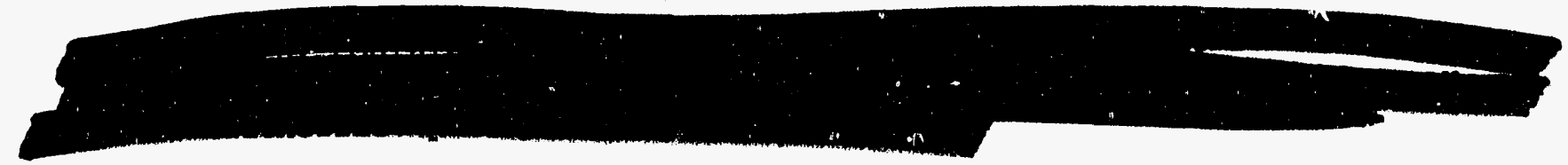

DISCLAIMER

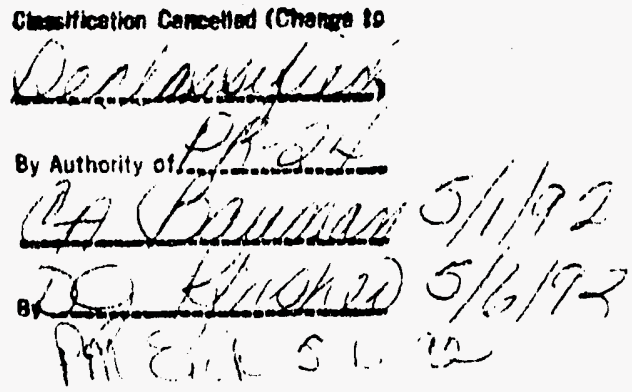

This report was prepared as an account of work sponsored by an agency of the United States Government. Neither the United States Government nor any agency thereof, nor any of their employees, makes any warranty, express or implied, or assumes any legal liability or responsibility for the accuracy, completeness, or usefulness of any information, apparatus, product, or process disclosed, or represents that its use would not infringe privately owned rights. Reference herein to any specific commercial product, process, or service by trade name, trademark, manufacturer, or otherwise does not necessarily constitute or imply its endorsement, recommendation, or favoring by the United States Government or any agency thereof. The views and opinions of authors expressed herein do not necessarily state or reflect those of the United States Government or any agency thereof.

\begin{tabular}{|c|c|c|c|c|}
\hline Route To: & PR No. & Location & Route Date & $\begin{array}{c}\text { Signature and } \\
\text { Date }\end{array}$ \\
\hline 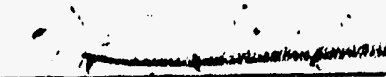 & 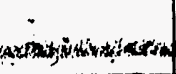 & 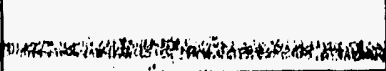 & $7 / 1,3,1969$ & \\
\hline Nom & 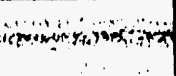 & 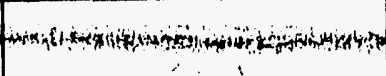 & 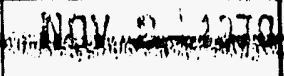 & 4 \\
\hline . & & & & \\
\hline
\end{tabular}

This document is 1 ased on work performed under United States Atomic Energy Commission Contract AT $(45-1)-1830$.

GROUP 1

Excluded from automatic downgrading and declassification 


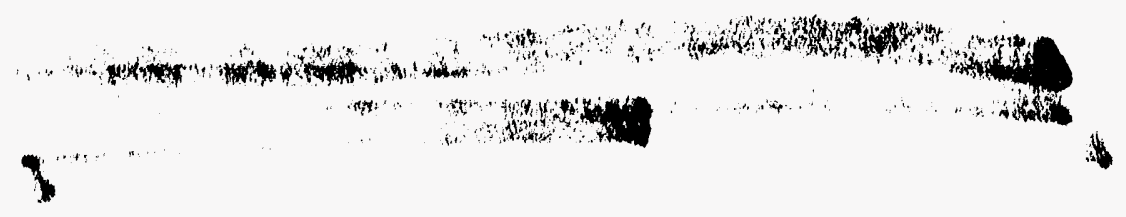

Printed in USA. Charge $\$ 1.05$. Available from the U. S. Atomic Energy Commission, Division of Technical Information extension, P. O. Box 62, Oak Ridge, Tenn. 37830 . Please direct to the same address inquiries covering the procurement of other classified $A E C$ reports. 


\section{DOUGLAS UNITED NUCLEAR}

1. $\therefore$ W. Ambrose

2. P. A. Carlson

3. J. W. Frymier

4. R. G. Geier

5. P. C. Jerman

6. W. K. Kratzer

7. R. W. Pitman

8. R. W. Reid

9. J. W. Riches

10. O. C. Schroeder

11. G. W. Wells

\section{BATTELLE - NORTHWEST}

12. F. W. Albaugh

13. G. J. Alkire

14. R. L. Dillon

15. J. W. Bartlett

16. J. R. Divine

17. J. J. Fuquay

18. B. Griggs

19. R. B. Hall

20. J. M. Nielsen

21. H. A. Kornberg

22. H. M. Parker

23. R. H. Perkins

24. W. B. Silker

25. C. J. Touhill

26. N. A. Wogman

27-31. Technical Information Files 


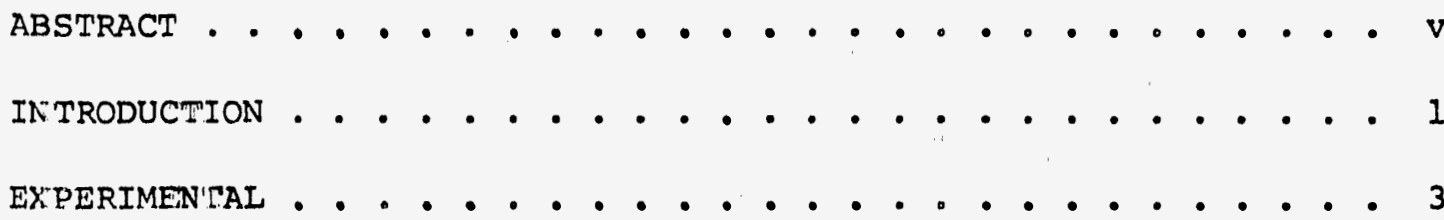
RESULTS AMID DISCUSSION

A. FILM FROM ALUMINUM PROCESS TUBES . . . . . . . . . . . 7

B. FILM FROM ALUMINUM CLAD FUEL ELEMENTS . . . . . • • • . 13 REFERENCES . . . . . . . . . . . . . . . . . . . . . . 21 TABLES

I Operating Conditions for Tubes and Fuel Columns . . . 4

I Deposition Constants for Inert Elements . . . . . . . 10

III Deposition Constants for Inert Elements . . . . . . . 16

IV Relative Concentrations of Inert Elements . . . . . . 18 APPENDICES

A-1 Radioisotopes Present on Surface Film-Tube 1367 . . . 22

A-2 " " " "Tube 137.0D . . . 23

A-3 " " " " -Tube 1465 . . . 24

B Radioisotopes Present in Tube Aluminum-Tube 1367 . . . 25

C-1 Inert Elements present in Surface Film-Tube 1367 • • . 26

C-2 " " " " "Tube 1370 •. . 27

$\mathrm{C}-3$ " " " " "Tube 1465. . . 28

D Radioisotope Contribution from Tube Corrosion. . . . . 29

E-1 Radioisotopes Present on Fuel Element Film-1166A . . . 30

E-2 Radioisotopes, " " " " . " . 31

E-3 " " " " " 
TABLE OF CONTENTS - cont'd.

F-1 Inert Elements Present on Fuel Eloment Surface - 1166A . . 33

$\mathrm{F}-2 \quad " \quad$ "

$\mathrm{F}-3 \quad$ "

" $\quad-1166 \mathrm{~B} \cdot .34$

"

" $\quad-0770$. 35

G-1 Calculated Residence Time of Elements - Tube 1367 . . . 36

$\mathrm{G}-2$

1

"

"

"

- Tube 1370 . . . 37

G-3

"

$"{ }^{\circ}$

- Tube 1465 . . . 38

$\mathrm{G}-4$

"

of Fuel Column - 1166A . . . 39

G-5

i"

"

"

"

$-1166 \mathrm{~B} \cdot . \cdot .40$

G-6

"

"

"

"

"

- 0770 .... 41 


\section{ABSTRACT}

The concentrations of inert elements and radioisotopes contained by the films on both fuel elements and aluminum process tubes were measured in selected samples taken from specimens of varying in-reactor exposures. The comounts of radioisotopes contained on a unit surface at any particular location on the three tubes increased with Zonger exposures, however, the differences were less noticeable in the case of isotopes of shorter halflife. Inert element concentrations were quite constant at a given location in the three process tubes, and the linear distributions could be described as an exponential function of distance. The linear distribution of inert elements on a fuel colum with sixty days exposure could also be described by this function although higher concentrations were present. A different deposition patterm was exhibited by two fuel colums of loner exposure.

Film composition was uniform along the length of the various process channels, with relative values approximating the respective ratios of the parent isotopes in process water. Corrosion of aluminum process tubes was shown to contribute only minor mounts to the radionuclides contained by the films on the tube surfaces. It is therefore concluded that most of the materials comprising the in-reactor film originated as impurities in the cooling water. 


\section{INTRODUCTION}

The complex films that form on the surfaces of the fuel elements and process tubes in the Hanford reactors are known to be the production site for many of the radioisotopes found in the effluent water. (1) and the radioisotopes contained by these films has received relatively little attention in the past. The purpose of this work was to better define these films, with respect to length of reactor exposure, location within the reactor, the surface upon which they are deposited; and subsequently gain additional insight on the mechanisms of their formation.

The films of interest are multiphase in nature, consisting of an aqueous corrosion product developed on the surface of the base metal and a surface film presumably formed by deposition of coolant impurities. The corrosion product formed on an aluminum surface is described as consisting of a thin barrier film of

at the metal interface, upon wich a relatively thick deposit of hydrated aluminum oxide exists. (2) This outer, or bulk film, attains a steady state thickness that is ciependent on the conditions of temperature, flow and radiation flux to which the aluminum is exposed. The bulk film is porous and presents numerous sites for absorption of impurities from its aqueous environment. The aluminum corrosion product is permeated and overlaid to varying degrees with an amorphous material mainly of compounds of iron and silicon which imparts a red to dark red-brown coloration to the film that diminishes in intensity until it ceases to appear on upstream surfaces. This film also presents additional sites for absorption of ions from the coolant, as well as providing a large reservolr of the impurities from which it is composed. Neutron reactions involving these materials result in production of radioisotopes, and owing to a long exposure period, a large inventory of radioactive material is developed. Exchange reactions and erosion of the film introduce a portion of these radioisotopes to the coolant and eventually to the Columbia River, thus becoming available for entry to the biosystems 
of the river.

Radiochemical analysis of a sample of film from an aluminum process tube showed a large inventory of many radionuclides associated with the corrosion film. (3) Comparison with the normal concentrations of these radiolsotopes in reactor effluent water showed that these film inventories were equivalent to many days of discharge, indicating a slow rate of release of these materials to the coolant.

The concentration and distribution of several long-lived radiolsotopes were measured in samples of $\mathrm{EIlm}$ removed from fuel elements selected from a column that had received $531.4 \mathrm{MWD} / \mathrm{Ton}$ exposure. (4) The integrated accumulation of the radioisotopes was described by a quadratic function of the accumulated length of exposed surface. The location of maximum radioisotone surface concentration was found to occur well downstream from the peak neutron flux and somewhat upstream of the point of maximum fuel element corrosion.

Richmond ${ }^{(5)}$ found nuclear radiation to increase both the amount of film deposited and the uniform corrosion of the aluminum. In this study, water, preheated to $90^{\circ} \mathrm{C}$ and flowed at a velocity of 8 feet per second past the column of dummy fuel test samples was discharged at a temperature of $95^{\circ} \mathrm{C}$. Under these conditions, measurable amounts of film were deposited even in the upstream outof-flux zone, and the film weights increased about fourfold in the region of maximum radiation intensity. These data are paralleled to a degree by investigations of redeposition of corrosion products under the influence of electron bombardment, in which the formation of an "activated" colloidal species was hypothesized. (6) The "activated" colloid was reported to have had a half-life of less than one second and tended to undergo deposition before its reversion to ground state.

The present study was directed toward definition of the influence of exposure and position within the reactor on the film inventory of both inert 
elements and radioactive isotopes. The chemical composition of the film was established from the data, the possible mechanisms of the absorption and deposition reactions were studied, and the average residence times for the various elements on the film were estimated. This information will be ugeful to those involved in devising methods by which the production and discharge of radiolsotopes from Hanford reactors can be minimized.

\section{EXPERIMENTAL}

Samples for this study were obtained from aluminum process tubes and uranium fuel colums exposed in the same general location in the Hanford D-reactor. In addition to their proximity, the tubes and fuel charges were selected on the basis of exposure to provide a means for evaluating the influence of this parameter on the quantities of both elemental and radioactive constituents contained by the surface films. The extruded aluminum tubes were made from 1100 aluminum alloy while the fuel elements were clad with 8001-F, an aluminum alloy containing $1 \% \mathrm{NI}$ and $0.6 \%$ Fe. The downstream spacers were of 6063-T6 aluminum which contains additional silicon and magnesium. The fuel elements were essentially right cylinders with a hole through the center to permit coolant flow across both the external and internal surfaces. Subsequent references to sample location will signify the longitudinal displacement from the downstream end of the tube.

During their exposure, tubes 1370 and 1465 contained both enriched and normal uranium fuel charges, and the terminal charges in both tubes were enriched metal. Tube 1367 was charged with a 32-piece natural fuel column, of which one piece ruptured necessitating removal of the tube from the reactor. Of the fuel columns selected for measurement, the two taken from tube 1166 were normal uranium, while that from 0770 was enriched metal. Pertinent information regarding the conditions to which these tubes and fuel charges were exposed are presented in Table I. The tube data represent the conditions which existed duxing the fuel cycle prior to tube removal. 
TABLE I - Operating Conditions For Tubes and Fuel Columns

\begin{tabular}{|c|c|c|c|c|c|}
\hline Sample & $\begin{array}{l}\text { Age at } \\
\text { Removil }\end{array}$ & $\begin{array}{l}\text { Average Tube } \\
\text { Power (kw) }\end{array}$ & $\begin{array}{l}\text { Coolant } \\
\text { Flow (gpm) }\end{array}$ & $\begin{array}{l}\text { Coolant } \\
\Delta T \text { (C) }\end{array}$ & $\begin{array}{c}\text { Average Thermal } \\
\text { Neutron Flux } \\
\text { (n/om } / \mathrm{sec})\end{array}$ \\
\hline Tube 1367 & 2 months & 1200 & 50 & 92 & $5.64 \times 10^{13}$ \\
\hline Tube 1370 & 10 months & 1348 & 49.4 & 103 & $5.98 \times 10^{13}$ \\
\hline Tube 1465 & 38 months & 1237 & 49.5 & 95 & $5.95 \times 10^{13}$ \\
\hline Fuel 1166A & 7 days & 1190 & 51.2 & 88.2 & $5.77 \times 10^{13}$ \\
\hline Fuel 1166B & 36 days & 1223 & 51.1 & 90.9 & $5.43 \times 10^{13}$ \\
\hline Fuel 0770 & 60 days & 1280 & 48.7 & 99.7 & $5.94 \times 10^{13}$ \\
\hline
\end{tabular}

Values listed for the average thermal neutron fluxes were calculated from tube power data and appropriate reactor parameters. Front to rear variations of the thermal neutron flux were taken from flux traverse data routinely obtained by personnel at the reactor.

Fuel columns to be sampled were preselected to facliftate thels discharge from the reactor as soon as possible after an outage. After manual removal of the first eight spacers in the downstream dummy pattern, the remaining dummies and the fuel elements were machine discharged and dropped into the pickup basin on the reactor rear face. Selected elements were then transferred to a shielded cask and transported to a Radiometallurgy Laboratory for treatment. Removal of the tubes from the reactor first involved longitudinal splitting by forcing a special cutting tool through the tube from the front to rear face. This tool has two cutting blades which are positioned against the sides of the tube, and as it is drawn through the tube, crimps the freshly cut surfaces in an inward direction. After splitting, the tube is pushed out the rear face and cut into suitable lengths with a powered gulliotine. Workable sized specimens were removed from the top half of tubes 1370 and 1465 with a hacksaw. Smaller samples of measured surface area, each of which appeared by visual analysis 
to retain a characteristic film were removed for analysis. Samples from tube 1367 were received as $3 / 4$ inch diameter punchings. As seen from the foregoing discussion, both the tubes and fuel alements underwent some rather tortuous treatment which was certainly no: conducive to maintenance of the surface film in an undisturbed condition.

The film coloration on downstream positions, outside of the neutron flux, was a rich reddish-brown. The film was much darker on flux-zone samples, attaining a maximum intensity at about fou:teen feet. From this point, the coloration diminished with each succeeding upstream sample, and was not observed above twentysix feet. The colored film was tenaciously bound to the surface of the further upstream samples. As the color of the film darkened, and presumably the film thickness increased, it became less adherent to the underlying surface.

The colored film, together with the aluminum oxide corrosion product, was quantitatively removed by immersion of the individual samples in hot $\left(90^{\circ} \mathrm{C}\right) 8 \mathrm{M}$ nitric acid which did not seriously attack the base aluminum. An attempt was made to remove the surface fiim from Tube 1367 samples by ultrasonic treatment. This treatment was only partially successful, especially with the upstream samples; however, the films removed by the two processes were analyzed individually to gain a measure of the relative depth within the film at which the various species were retained. The stripping solutions were evaporated to a low volume, which dissolved most of the film material. An insoluble residue, subsequently determined to be dehydrated silica, was removed by centrifugation and the supernatant liquid diluted to known volume.

Suitable aliquots of these solutions were evaporated on counting planchets, and the concentrations of the gamma-emitting radioisotopes were measured by multidimensional gamma ray spectrometry. (7) Measurement of the samples as soon as pussible after preparation provided spectra from which the concentrations of ${ }^{64} \mathrm{Cu}$, 
${ }^{72} \mathrm{Ga},{ }^{76} \mathrm{As},{ }^{140} \mathrm{La},{ }^{152 \mathrm{~m}_{\mathrm{EL}} \text { and }}{ }^{239} \mathrm{~Np}$, and in one instance ${ }^{56} \mathrm{Mn}$ and ${ }^{65} \mathrm{Ni}$ were determined. After decay of these short-lived isotopes from the samples, a second measurement provided assay for the amounts of ${ }^{46} \mathrm{Sc},{ }^{51} \mathrm{Cr},{ }^{54} \mathrm{Mn},{ }^{58} \mathrm{Co},{ }^{59} \mathrm{Fe},{ }^{60} \mathrm{Co},{ }^{65} \mathrm{Zn}$, ${ }^{95} \mathrm{Zr},{ }^{124} \mathrm{Sb}$ and ${ }^{181_{\mathrm{Hf}}}$ in the samples. ${ }^{32} \mathrm{p}$ was measured by beta counting after isolation of the radiophosphorus by a solvent extraction technique. ( 8 ) Mathematical resolution of all gamma ray spectra were programmed on a Univac-1107 computer.

The amounts of several inert materials contained by the film samples were determined by neutron activation analysis. Samples of the dissolved film, together with standards containing known quantities of the elements of interest were individualiy encapsulated in quartz ampules and irradiated in one of the Hanford production reactors. One sample, which was exposed to the neutron flux for approximately one hour, was analyzed for the parent concentrations of the short-lived nuclides previously mentioned, plus nickel and manganese. Any interference from the short-lived nuclides originally contained by the sample was eliminated by allowing these isotopes to decay from the sample before re-irradiation. The long-lived radioisotope parent concentrations were determined from a second aliquot of the samples which were coirradiated for 24-72 hours with appropriate standards. Interpretation of the data was complicated by the presence of radioisotopes remaining from the originai sample, which necessitated determination of the amount of radioisotope formed during the neutron activation by difference between the quantities present in the original and re-irradiated samples. This procedure introduced a relatively large statistical exror in many instances. The aluminum ion concentration in the dissolved film samples was determined colorimetrically by the 8-hydroxquinoline method, and silica was determined gravimetrically by weighing the residue from the original sample dissolution. 


\section{RESULTS AIND DISCUSSION}

\section{A. Film From Aluminum Process Tubes}

\section{Radioisotopes}

The results of radiochemical analysis for those isotopes present in the 1 im samples from the three tubes are tabulated in Appendix A. These values are presented in units of disintegrations per minute per square centimeter corrected to time of reactor shut down, and are located with reference to the distance from the downstream end of the tube. Values for the short-lived radioisotopes were not obtained for Tube 1367, as the samples were received two months after the tube had been removed from the reactor. The approximate percent error at the one sigma level due to counting statistics and the uncertainty introduced in the calculation is presented below each column.

Considerable scatter was observed in the data obtained from adjoining locations especially in Tubes 1370 and 1465. For example, the samples taken from the 14 and 20 foot locations in Tube 1465 revealed high surface concentrations of the various radioisotopes in reference to the adjacent samples. The same is also true for the sample taken from the 20 foot location of Tube 1370 . It is presumed that this results from film loss during the tube removal operations and from the fact that the in situ film is not a static entity, but is continually being replaced both by surface reaction and by erosion. Those samples that contain high radioisotope values perhaps reflect a relatively undisturbed film, and represent the maximum amount of radioisotopes that might be encountered. Conversely, data from the 17 foot sample from the Tube 1465 suggest that the film at this location had sloughed previously and the existing film"had not been in place for a sufficienc time to attain the degree of radioisotope production exhibited by adjacent samples.

In general, the amounts of radiolsotopes contained on a unit surface at any 
particuiar location in the three tubes increased with relation to the length of exposure, however, the differences were less noticeable in the case of isotopes of short half-life. The major exception was ${ }^{51} \mathrm{Cr}$, which was present in higher concentrations on the surface of Tube 1367, the two-month-old tube, than on 1370, which had ten months of service. No inordinately high concentrations of fission products (see ${ }^{95} \mathrm{zr}$ ) were observed on the film taken from samples of Tube 1367, which contained a ruptured fuel element at the time of its renioval. The adsorption of released fission products was negligible due perhaps to the rupture debris not being in a form suitable for retention by the film. The linear distributions of the radioisotopes presented some interesting characteristics. Radionuclide concentrations exhibited a maxima between 10 and 20 feet. The distribution in Tube 1367 was quite narrow and located between 14 to 17 feet while the distribution curves for Tubes 1370 and 1465 were much broader, with maxima approximately 20 feet from the end of the tubes. In none of the cases studied did the radiolsotope distribution follow the pattern described by the neutron flux, although both the neutron flux and radioisotope concentration in the two older tubes attained maximum values ahout 20 feet from the rear of the tube. There was either relatively ilttle production or retention of radiolsotopes in the upstream $8: 010$ feet of the active zone of the reactor. The inventory of radiousotopes contained by the process tube films represents the equivalent of many days discharge through the effluent system, and the presence of such a large reservoix of radioactive matexials certainly can be assumed to contribute significantly to the contamination in the effluent water by slich mechanisms as ion exchange, corrosion, and erosion.

Some definition of the depth at which the individual radioisotopes were contained in the film can be inferred from the data obtained from Tube i367. The ultrasonic treatment to which the samplos were initially exposed removed only the loosely bound colored surface $f 1 \mathrm{~lm}$, and was most successfully applied to

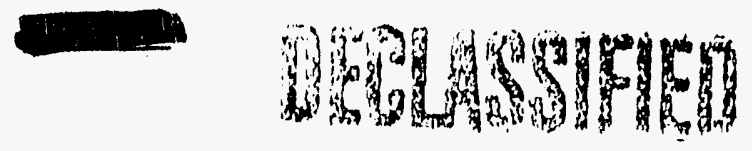


the specimens from the $9.5,12.5$ and $26 \mathrm{ft}$ locations. The removal of this colored film was only partially complete; therefore, any radioisotope that occurred primarily with this fraction would have existed on the surface, and as such, would not have been removed either from greater depths within the film or from the base metal. Most of the radioisotopes were predominantly associated with the surface film; however, the data show a significant amount of ${ }^{60}$ co contained in the subsurface matrix. As was previously noted, the base aluminum and its associated impurities could provide a significant source from which radioisotopes could be introduced to the coolant by corrosion. Samples of the defilmed aluminum specimens from Tube 1367 were analyzed to determine the magnitude of the source. These data, presented in Appendix B, reveal that relatively large quantities of several radioactive species are contained in the aluminum. The potential contribution of this source to the coolant concentrations will be discussed in a later section. It was ascertained that less than one percent of the radionuclides removed during film stripping processes was derived from the activity contained in the base metal.

\section{Parent Isotopes}

The concentrations of inert elements contained by the films are given in Appendix C. The concentration of any particular element was relatively constant at a given location in the three process tubes which leads to the conclusion that the degree of film formation was relatively independent of the length of exposure between the limits of two and thirty-eight months. Statistical analysis of the data from the individual tubes showed that the distribution of the inert materials in Tube 1465 differed only slightly from those in the other two tubes there are numerous examples throughout the data in which either uniform or decreased deposition of a given element occurred in successive downstream, out-of-flux sample locations. The data from in-flux locations, however, can be described mathematically by the exponential function

$$
c=a e^{-b D}
$$


where: $C$ is the concentration of the element in $\mathrm{mg} / \mathrm{cm}^{2}$

$D$ is the distance from the downstream end of the tube in feet

$a$ and $b$ are constants characteristic of each element.

of the elements measured, only gallium, europium, and zirconium did not exhibit a distribution pattern that could be described by this model. Gallium occurred in a relatively constant amount in successive samples. As a naturally occurring impurity of aluminum, it might be expected that gallium would follow the trend found for aluminum. The fact that it did not suggests that the two materials were derived from different sources. Aluminum deposition was qualitatively similar to the majority of the other elements, and may have been deposited from coolant impurities, while the gallium may well result as a corrosion product from the tube material. The data for inert zirconium and europium were too limited and scattered, which prevented a meaningful behavioral description of these materials. Table II - Deposition Constants For Inert Elements

\begin{tabular}{|c|c|c|}
\hline Element & $\mathrm{a}\left(\mathrm{\mu g} / \mathrm{cm}^{2}\right)$ & $\underline{b\left(\text { feet }^{-1}\right)}$ \\
\hline$M n$ & 7 & .154 \\
\hline $\mathrm{Ni}$ & 13 & .077 \\
\hline U & 1.5 & .087 \\
\hline Ia & 0.4 & .116 \\
\hline As & 0.6 & .099 \\
\hline $\mathrm{Sb}$ & 0.17 & .099 \\
\hline $\mathrm{zn}$ & 180 & .116 \\
\hline Co & 0.56 & .116 \\
\hline $\mathrm{Fe}$ & 1000 & .126 \\
\hline $\mathrm{Cr}$ & 140 & .087 \\
\hline Sc & 0.12 & .116 \\
\hline Al & 1100 & .107 \\
\hline $\mathrm{Cu}$ & 24 & .099 \\
\hline
\end{tabular}




\section{WEFED}

The constants " $a$ " and " $b$ " determined from the data for the various elements are presented in Table II. The values for the constant "a" are the maximum projected concentration of the inert element deposited in the downstream reaches of the tube and " $b$ " is a function of the slope of the deposition curve. Aluminum and iron were the most abundant species in the film with concentrations approaching $1 \mathrm{mg} / \mathrm{cm}^{2}$. other metalif elements fairly abundant in the film include $\mathrm{Zn}, \mathrm{Cr}, \mathrm{Cu}$ and $\mathrm{N}$. Silica was observed during the film dissolution treatment, but due to the small sample size, was not gravimetrically determined in these samples.

The slope coefficient " $b$ " of the individual elements are remarkably constant and, in general, correspond to a distance of 6-8 feet for a twofold parent isotope decrease. The only deviation from this constancy was shown by manganese. which exhibited a steeper slope. In other reactor systems, manganese was reported to have behaved differently from other elements: (9) Perhaps this element acts as a "catalyst" and enhances the deposition of the other materials. The constant values for "b" reflect a uniform film composition throughout the length of the prosess tube. It is significant that the relative concentrations of the valious eiements, with the exception of chromium, were quite similar to those reported for process water. ${ }^{12,10 i}$ thus 1 t seems 11 kely that a majority of the I:Im consticuents were derived from the cooling water impurities.

In the course of neutron activation analysis of the film samples no significant evidence of halides was encountered. No carbon dioxide evolution characteristic of carbonates was observed during the acid dissolution of the film from the original samples. From these crservations and the data presented above, It is postulated that the films were composed primarily of hydrous metal oxides and silicates.

The differences in the presence and amount of colored surface film between this work and Richmond's experiment ${ }^{\prime 5}$ qualitatively emphasize the importance of temperature and radiation on the deposition process. The presence of colored

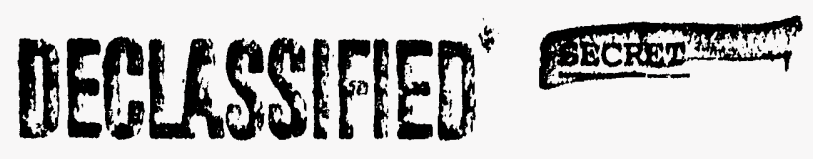


Eilm, deposited fxom water preheated to $90^{\circ} \mathrm{C}$ was observed on all samples of a charge that extended from the front face of the reactor to the rear face. The amount of film deposited was reported linearly as a function of the radiation intensity to which the specimen was exposed. In no instance known to this writer has a colored film been observed in the upstream, out-of-flux region of aluminum production process tubes, and even the fuel elements in the upstream portion of a fuel column are devoid of coloration. It thus appears that deposition, or at least the formation of a depositable species, is a temperaturecontrolled reaction. After attaining some critical temperature, tranşormation of soluble coolant impurities to a depositable state would be initiated, and would approach completion as the coolant temperature increased during passage through the reactor. Radiation would unquestionably influence deposition, but its effect is speculated to be second order.

\section{Radioisotopes from Corrosion}

An estimate of the maximum contribution of radioactive contaminants from the base aluminum to the activity contained by the surface film can be made by assuming that these impurities are corroded at the same rate as the aluminum, and that the aluminum found on the surface film resulted from corrosion of the base material. The fractional amount of the activity contained by the base metal (Appendix C) that would be found in the surface film would be directly proportional to the ratio of the weight of aluminum in the film to that in the base metal samples. Computation of these values provided the results shown in Appendix D. Corrosion of the base metal could have contributed from one to four percent of most of the radioisotopes present in the film taken from the 26 foot sample, and from 7 to 128 of the ${ }^{58} \mathrm{Co},{ }^{95} \mathrm{zr}$ and ${ }^{181} \mathrm{Hf}$. In the region of maximum radinisotope concentration, 38 of the ${ }^{58} \mathrm{Co}$ and ${ }^{60} \mathrm{Co}$ and less than 18 of the remaining radioisotopes could have been derived from the base aluminum. Enrichment of impurities in the surface film with respect to aluminum is considered unlikely

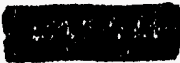


based on the solubtlity products of the respective oxides, and it. is therefore concluded that the base metal is not a significant source of the radioisotopes observed on the surface film.

\section{B. Film From Aluminum Clad Fuei Elements}

\section{Radioisotopes}

The results of radiochemica: analyses of nuclides contaired by the sampies from the three ruel columns are presented in Appendix E. These values, corrected to time of reactor shutdown, are presented as disintegrations per minute per square centimeter and are located with respect to the distance from the downstream end of the process tube.

Maximum concentrations of the radioiscitopes in all three fuel columns occurred ititeen to eighteen feet from the downstream end of the charge. The concentration profiles for the three columns were uniform which cancels any assumption Involping piduction location dependency on the length of exposure. The concentration frofices were divided anto two dustinct olasses. The first, in which the Amount of adicisotope retained on upstream surface was much lower than the maximum

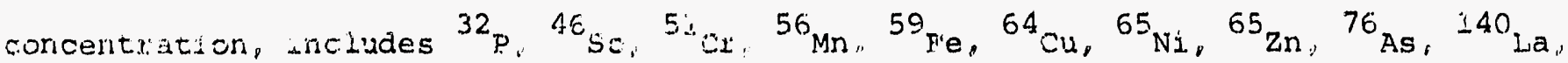
$152 \mathrm{mn}$ Eu a d peshaps ${ }^{60} \mathrm{Co}$. The second group, consisting of ${ }^{24} \mathrm{Na},{ }^{58} \mathrm{Co},{ }^{72} \mathrm{Ga},{ }^{95} \mathrm{Zx}$ 。

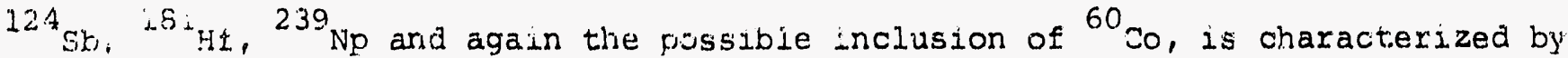
a patters that more nearly appzoaches the neutron flux distribution. This suggests that the jatter group was derived from impuritzes present in the fuei-cladding a Lone, and by inference, the tormer group of radiolsotopes was formed by activation of inert materials deposited on the suxface of the fued. elements. The apparent contradiction to this nypothesis is that. ${ }^{65} \mathrm{~N}$. does not appear with the eiements that were assigned to the fuel-ciladaing lmpur $\downarrow$ ties. This could resuit from the large errots associated with ${ }^{65} \mathrm{~N}$ i concentration measurements which wexe due to its very low disintegration rate and correction factors compensating for the contribution of other isotopes $c:$ the ${ }^{65} \mathrm{NL}$ energy region. It is of interest 
to note the different distribution patterns shown by ${ }^{54} \mathrm{Mn}$ and ${ }^{59} \mathrm{Fe}$ which are activation products of an iron parent. The ${ }^{54} \mathrm{Mn}$ formed on surtuce layers could be preferentially released from the film with respect to ${ }^{59} \mathrm{Fe}$, while the remaining matertal would be formed at depth. Release could occur due to a higher relative solubility, or emission from the film by a szilard-Chalmers recoil reaction. Neptunium-239 was present in relatively high concentrations on the upstream positions of all of the fuel columns. Uranium, its parent, is not present as a significant contaminant of $8001 \mathrm{~F}$ alloy ${ }^{(1)}$; therefore, it must be assumed that the surfaces of the fuel elements were sufficiently contaminated during manufacture to provide the observed results. At least a fraction of the production of ${ }^{60} \mathrm{Co}$ could be expected to result from the ${ }^{60} \mathrm{Ni}(n, p){ }^{60} \mathrm{Co}$ reaction on the nickel additive to $8001 \mathrm{~F}$ aluminum, which could explain the apparent dual behavior of ${ }^{60} \mathrm{Co}$.

Within reasonable limits, equal surface concentrations of ${ }^{24} \mathrm{Na},{ }^{72} \mathrm{Ga}$, $152 \mathrm{~m}$ Eu and ${ }^{239} \mathrm{~Np}$ were present at any particular location on all three fuel columns. The two columns with respective exposures of 60 and 34 days contained what appeared to be steady state surface concentrations of ${ }^{46} \mathrm{Sc},{ }^{51} \mathrm{Cr},{ }^{95} \mathrm{Zr}$ and ${ }^{140} \mathrm{La}$, but the remaindex of the radiolsotopes increased in concentration with increasing exposure. The duration to which these specimens were exposed was too short for attainment of an equilibrium concentration of radioisotopes of fairly long half-life even had there been a fast buildup of the parent material to its steady state concentration. The fact that ${ }^{46} \mathrm{Sc},{ }^{51} \mathrm{Cr}$ and ${ }^{65} \mathrm{Zn}$ did attain or approach steady state means that there was also a fairly rapid exchange of their respective parents between the surface film and the environment. Copper-64 and 76 As concentrations increased with exposure, which suggests that the parent material deposition process was relatively slow, and that the amount of their respective parents increased with time.

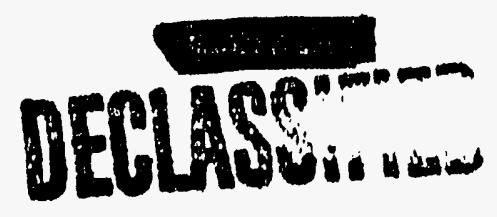


With only a few exceptions, the surface concentration of radiolsotopes on fuel elements from Tube 0770 was higher than observed on the surfaces of the process tube 1367 that recelved a two month exposure. The exceptions were ${ }^{51} \mathrm{Cr}$ and ${ }^{95} \mathrm{zr}$, both of which were lower in concentration, and ${ }^{59} \mathrm{Fe}$ which was present in equal amounts on both surfaces. The fast neutron flux at the fuel element surface is significantly higher than exists at the process tube interface and would explain in part the increased amounts of ${ }^{54} \mathrm{Mn}$ and ${ }^{58} \mathrm{Co}$ which are produced by fast neutron reactions. Conversely, the thermal neutron flux at the fuel element surface is less than at the tube wall. The higher radiolsotope concentrations, therefore, must reflect either a greater concentration of the respective parent materials or an extended residence ilme of the film constituents on the fuel element surface.

\section{Parent Isotopes}

The measured quantities of inert chemical elements contained by a unit surface area of film from the various fuel element samples are given in Appendix F. The relatively high degree of variability in these results reflects the effect of remote handing operations and the resultant disturbance of the surface layers. In addition, these samples were stored underwater to provide continuous removal of seif-generated heat, thus, the distinct possibility of leaching of the film component.s was present.

It is immediately apparent that the linear distributions of inert elements, at least in the two shorter exposure fuel columns, are not descrthed by the exponential function of distance employed in the previous section. Among the variables present that could influence the deposition of impurities are surface and water temperatures, and the neutron fluxes at a given location. An attempt was made to evaluate relationship of the measured deposition patterns with respect to the surface temperatures, which were considered to be a function of the neutron flux and water temperature variables.

An inert element is deposited on both the inney and outer surface of a fuel 
element. To accommodate the different areas of these two surfaces, and their varying temperatures, the total deposition on a fuel element was desoribed by an equation of the form:

$$
c=a e^{-b T_{1}}+0.29 a e^{-b T_{2}}
$$

where $C=$ Elemental concentration $\left(\mu \mathrm{g} / \mathrm{cm}^{2}\right)$

$$
\begin{aligned}
& \mathrm{T}_{1}=\text { Temperature of outer surface in }{ }^{\circ} \mathrm{C} \\
& \mathrm{T}_{2}=\text { Temperature of hole surface in }{ }^{\circ} \mathrm{C} \\
& \mathrm{a}=\text { Elemental concentration at } \mathrm{T}=0\left(\mathrm{\mu g} / \mathrm{cm}^{2}\right) \\
& \mathrm{b}=\text { slope coefficient }\left(1 /{ }^{\circ} \mathrm{C}\right)
\end{aligned}
$$

\begin{tabular}{|c|c|c|c|c|c|c|}
\hline \multirow{3}{*}{$\begin{array}{c}\text { Element } \\
\text { Sc }\end{array}$} & \multicolumn{2}{|c|}{ Fue 1 1166A } & \multicolumn{2}{|c|}{ Fue 1 1166B } & Euel 0770 & \multirow[b]{2}{*}{$\underline{b}$} \\
\hline & $\underline{a}$ & $\underline{b}$ & $\underline{a}$ & $\underline{b}$ & $\underline{a}$ & \\
\hline & .00022 & $.053 \star$ & .00057 & $.050 *$ & $-\infty$ & -- \\
\hline $\mathrm{Cr}$ & .130 & $.039 \star$ & .395 & $.038 *$ & 10.3 & .0057 \\
\hline $\mathrm{Fe}$ & 22.2 & .0063 & 12.67 & $.020 *$ & 23.7 & .0043 \\
\hline Co & .001 & .0034 & .0061 & .0038 & .0149 & -.0001 \\
\hline $\mathrm{Zn}$ & 1.33 & $.017 \star$ & 11.97 & .0033 & 6.60 & .0123 \\
\hline $\mathrm{Cu}$ & 2.55 & -.015 & 1.00 & $.0098^{\star}$ & 1.00 & $.0103 *$ \\
\hline $\mathrm{Ga}$ & .0425 & .0070 & .072 & .00015 & .109 & .0090 \\
\hline As & .0085 & .0052 & .031 & $.0116^{\circ}$ & .129 & $.0087^{\circ}$ \\
\hline La & .00027 & $.0564 *$ & .0017 & $.0524^{*}$ & .115 & .0092 \\
\hline Eu & .00003 & $.0387 \star$ & .00009 & $.0401^{*}$ & .0015 & $.0109^{\circ}$ \\
\hline$U$ & .125 & .0014 & .840 & .0048 & .728 & .0098 \\
\hline$M n$ & .0080 & $.0343 *$ & .0265 & $.0223 *$ & .285 & .0104 \\
\hline Al & 279 & $.0084^{\circ}$ & 300 & -.0018 & 728 & $.0100^{\circ}$ \\
\hline Si & 41.9 & $.0040 \star$ & 7.97 & $.0186 *$ & 16.5 & $.0103 *$ \\
\hline $\mathrm{Zr}$ & 3.40 & .0084 & 57.5 & -.0013 & 48.1 & .0101 \\
\hline $\mathrm{Sb}$ & .00083 & $.0168 *$ & .0603 & -.0206 & -- & -- \\
\hline $\mathrm{Ni}$ & - & -- & 2.83 & $.0119^{\circ}$ & 17.3 & .0096 \\
\hline $\mathrm{Hf}$ & .0052 & .0022 & .0083 & $.0135^{\star}$ & -- & -- \\
\hline$\star$ & indicates slope & signifi & nce at the & $95 \%$ confidence & $\operatorname{limit}$ & · \\
\hline
\end{tabular}

By fitting the data to the model, the values for the coefficients "a" and "b" (Table III) were obtained.

TABIE III - Deposition Constants for Inert Elements

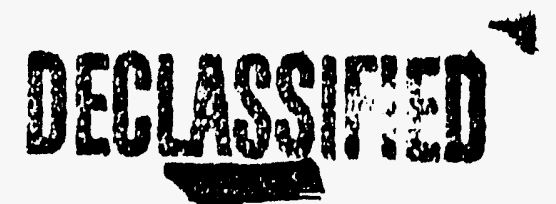


Statistical slope significance and agreement in the individual slope ooefficlent "b" was found for the elements Sc, Cr, La, Eu, Mn and Si deposited on the two fuel charges taken from channel 1166. With the exception of 51 , the values for the coefficient " $a$ " Increased with exposure for all of these elements, which indicates an increased deposition with time. In addition to these six elements, slope significance at the 908 confidence limit was obtained for elght other elements on these two fuel charges.

The lack of slope signiflcance for the data from fuel 0770 indicates that this model does not correctly describe all data. The variations in elemental surface concentrations for this fuel charge can be reasonably described by the model employed in a previous section for the tube film data. With the exception of uranium, nickel and zirconium, the slopes given in Table II are equally applicable to the elemental distribution in fuel 0770 , although the intercept, "a", differs in several instances. It thus appears that the eventual distribution of inert elements on both tube and fuel element surfaces decreases exponentially with distance, however, the initial deposition is a function of some operating parameter such as temperature.

The relative amounts of the various inert elements present on the surfaces of the fuel pilices and process tubes compare quite well as is shown in Table IV. These values normalized to iron, are compared with ratios observed in reactor process water. 
TABLE IV - Relative Concentrations of Inert Elements

(Iron Concentration $=1.0$ )

Element

Fe

Sc

$\mathrm{Cr}$

Co

$\mathrm{Zn}$

$\mathrm{Sb}$

$\mathrm{Cu}$

$\mathrm{Ga}$

As

La

U

$\mathrm{Mn}$
Fue $1(0770)$ *

1.0

.0002

.88

.0003

.78

.0004

.046

.004

.004

.002

.002

.011
Tubes * *

1.0

.0001

.14

.0006

.18

.0002

.024

$-$

.0006

.0002

.002

.007
Process Water

1.0

.00009

4.4

.0013

.36

.0006

.062

.0007

.005

.002

.002

.014

* Averaged from concentrations from all samples

** Determined from "a" values in Table II

Nickel and aluminum concentrations were between ten and one hundred times higher on the fuel element surfaces than were found on the samples from process tubes. This probably reflests dissolution of some base aluminum auring the film removal operation in the shielded facility. The similarity between the relative elemental concentrations in the reactor films and process water is striking. It is difficult to envision a mechanism by which a group of materials of such diverse chemical properties could be removed from the water in equal degree. This single feature should be investigated thoroughly in future researches.

\section{Residence Times}

The exposure required to produce the observed amount of radioisotope from the measured quantity of inert parent matertal in the film is described

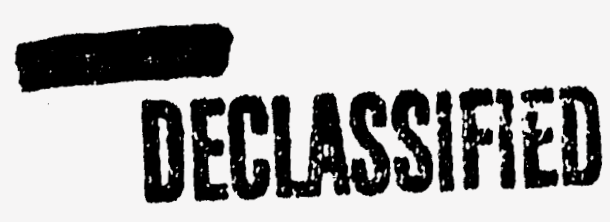


by the equation:

where:

$$
T=\ln \left[1-\frac{d / m}{N \sigma f}\right] / \lambda
$$

$T$ is the residence time in days

$\mathrm{d} / \mathrm{m}$ is the disintegration rate of a given radioisotope

$\mathrm{N}$ is the number of parent atons in the film

$f$ is the neutron flux in $\mathrm{n} / \mathrm{cm}^{2} / \mathrm{min}$

$\sigma$ is the neutron absorption cross-section in $\left(\mathrm{cm}^{2}\right)^{-1}$

and $\lambda$ is the decay constant in days ${ }^{-1}$.

Substituting values from the preceding sections, the average residence times were calculated for each specimen from the tubes and fuel columns and are presented in Appendix G.

There was no evidence to indicate that the residence time varied along the length of either the tubes or fuel columns. Parameters such as neutron flux and temperature per se apparently do not greatly influence the retention periods of the various species which indicates an association of these materials with the surfaces. This association may be a chemical reaction, or surface absorption by the corrosion product with the retention period being governed by the replacement of regeneration rate of the underlying matrix.

The residence period for the long-lived daughter parent pairs increased with length of exposure in both the tube and fuel surface series. The residences, on fuel element surfaces, were found to approximate one-half of the total exposure. This could result from continued irreversible deposition of these materials throughout the exposure of the fuel elements, but more probably reflects the non-exchangeability of the material held at depth within the film and the more exchangeable nature of that at the surface. The calculated residence for chromium was consistently shorter than found for the other macro- 
constituents, which could reflect a mass action effect resulting from the relatively high concentration of $\mathrm{Na}_{2} \mathrm{Cr}_{2} \mathrm{O}_{7}(1 \mathrm{ppm})$ in the coolant.

The short-lived parent-daughter pairs were generally found in concentrations that indicated retention periods sufficiently long to attain radioactive equilibrium. The most notable exceptions were the calculated values for uranium, which could have resulted from an error in the value employed for the neutron absorption cross-section.

With the possible exception of zinc, the various long-lived parentdaughter pairs resided for significantly longer periods on the fuel element surfaces as compared with the tube surfaces. This, together with the higher concentration of parent materials found on the fuel surfaces, offers an explanation of results from past work in which it was deduced that two-thirds of many of the radioisotopes in reactor effluent were produced on the fuel element surfaces. The reason for longer residence on the fuel surfaces is not known. It could result from the higher heat flux through the fuel jacket, or perhaps a potential gradient generated by an electron flux from decay of fission products in the fuel. This effect cuuld well provide the basis for future study.

\section{DECLASZHFD}

and 


\section{REFERENCES}

1. R.W. Perkins. "Source of Reactor Effluent Water Radioisotopes," HW-69969, May 1961。(SECRET)

2. MoS. Hunter and $P_{0}$ Fowle. "Naturally and Thermally Formed oxide Films on Aluminum," Jo Electrochem. Soc. vol。 Z03, pp.482-485. 1956.

3. R。W. Perkins。 "Parent Isotope Concentrations in Reactor Process Tube Filme" HW-73337, pp, 146-147。 January 1962。

4. L. D. Perrigo. "Radionuclide Distribution in Fuel Column Films: Progress Report," HW-79130. October 1963. (SECRET)

5. R. B. Richmond. "Radiation Effects on Aluminum Filming and Corrosion," HW-76642。 February 1963.

6. G. P. Simons. "Van de Graaff Study: Third Interim Report on the Deposition of Corrosion Products Under Irradiation, "WAPD-PT-II, pp. 18-28. December 1958.

7. R. W. Perkins. "An Anticoincidence-Shielded Multidimensional Analyzer," Nuclear Instr. and Methods, vol, 33, pp.72-76. 1965.

8. W. B. Silker, "Radiochemical Determination of Phosphorus-32," Ana? Chem. vol。 28, pp. 2783-3. 1956.

9. J.W. Bartlett. Personal communication. Pacific Northwest Laboratory, Richland, Washington.

10. W. B. Silker. "Water Treatment Variables-Nitrate System," BNWL-CC-1055, February 1967.

11. P. T. Goldman and J. R. Roesser. "Chart of Nuclides," 9th edition. November 1966. 
APPENCIX $A-1$

RADIOISOTCPES PPESENT ON SURFACE FIL:A - TUBE-1367

(2 months exposure)

$\mathrm{dpm} / \mathrm{cm}^{2}$

Distance From Downstream End of Tube $(f t)$

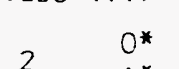

$6.5 \quad \begin{array}{ll}0 \\ 1\end{array}$

$7.5 T^{*}$

9.50

$11 \quad T$

$12.5 \quad$

14

16

19

26

Aprox. Error

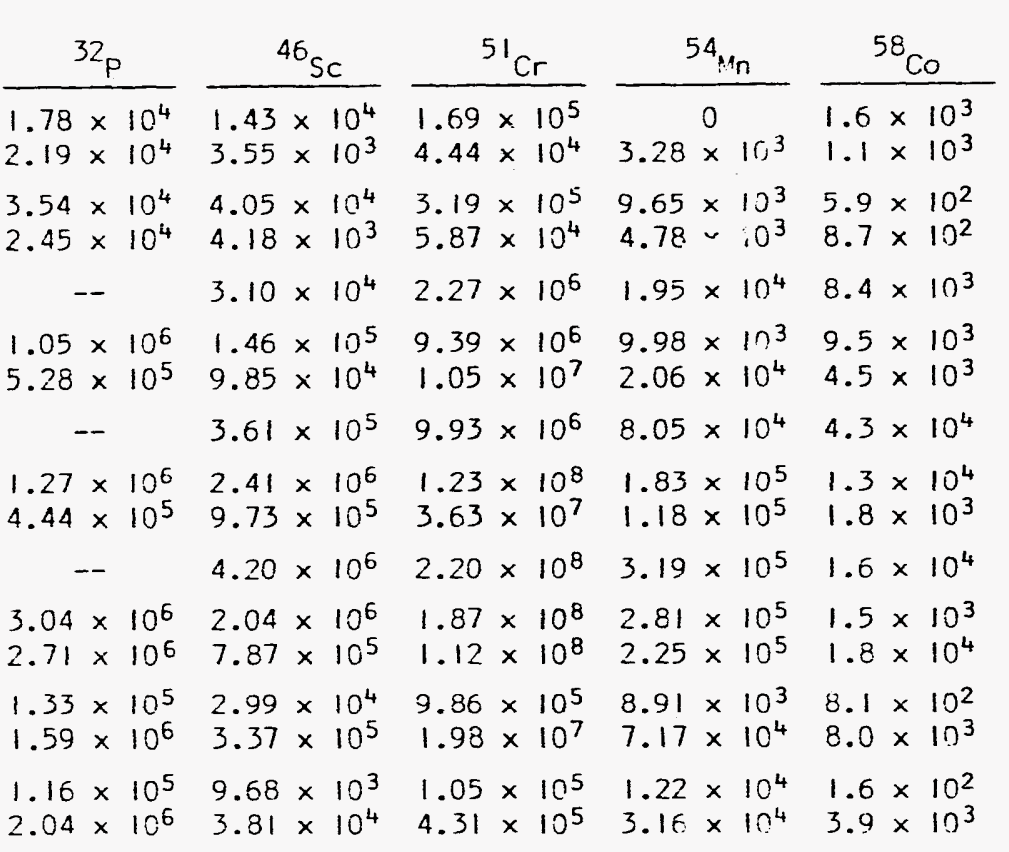

\begin{tabular}{|c|c|c|c|c|}
\hline $\mathrm{Fe}$ & $\mathrm{Co}$ & ${ }^{5} \mathrm{Zn}$ & $2 r$ & ${ }^{44} \mathrm{Sb}$ \\
\hline $\begin{array}{l}\times 10^{1} \\
2 \times 10\end{array}$ & $\begin{array}{l}45 \times 10 \\
90 \times 10\end{array}$ & $\begin{array}{l}C 9 \times 10^{4} \\
89 \times 10^{4}\end{array}$ & $\begin{array}{l}13 \times 10^{5} \\
36 \times 10^{4}\end{array}$ & $\begin{array}{l}.3 \times 10^{2} \\
.3 \times 10^{1}\end{array}$ \\
\hline $\begin{array}{l}0 \times 10^{1} \\
4 \times 10\end{array}$ & $\begin{array}{l}5 \times 10 \\
0 \times 10\end{array}$ & $\begin{array}{l}3 \times 10 \\
6 \times 10\end{array}$ & $\begin{array}{l}12 \times 10^{4} \\
16 \times 10^{3}\end{array}$ & $5 \times$ \\
\hline $43 \times 10^{4}$ & $36 \times 10^{4}$ & $66 \times 10^{4}$ & $37 \times 10^{4}$ & 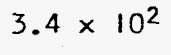 \\
\hline $\begin{array}{l}75 \times 10 \\
45 \times 10\end{array}$ & $\begin{array}{l}38 \times 1 \\
39 \times 1\end{array}$ & $1 x$ & $\begin{array}{l}02 \times 10^{6} \\
15 \times 10^{4}\end{array}$ & $x$ \\
\hline $.74 \times 10^{5}$ & $5.38 \times 10^{4}$ & $.84 \times 10^{5}$ & $82 \times 10^{6}$ & 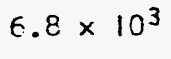 \\
\hline $\begin{array}{l}.82 \times 10^{6} \\
.83 \times 10^{6}\end{array}$ & $\begin{array}{l}66 \times 10^{4} \\
.05 \times 10^{4}\end{array}$ & $\begin{array}{l}74 \times 10 \\
70 \times 10\end{array}$ & $\begin{array}{l}67 \times 10^{5} \\
02 \times 10^{5}\end{array}$ & $3 \times$ \\
\hline $.02 \times 10^{6}$ & $3.82 \times 10^{4}$ & $20 \times 10^{6}$ & $.88 \times 10^{5}$ & 1.2 \\
\hline $\begin{array}{l}.32 \times 10 \\
.85 \times 10\end{array}$ & $.94 \times 1$ & $6 \times 1$ & $\begin{array}{l}0 \times 10^{5} \\
6 \times 10^{4}\end{array}$ & 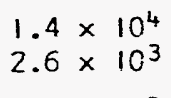 \\
\hline $\begin{array}{l}.27 \times 10 \\
.31 \times 10\end{array}$ & $\begin{array}{l}4.28 \times 1 \\
1.84 \times 1\end{array}$ & $3.21 \times$ & $\begin{array}{l}6 \times 10^{4} \\
1 \times 10^{4}\end{array}$ & $x$ \\
\hline $\begin{array}{l}.24 \times \\
.10 \times\end{array}$ & $\begin{array}{l}6.48 \times 1 \\
1.49 \times 1\end{array}$ & 26 & 0 & 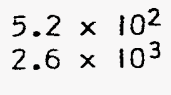 \\
\hline
\end{tabular}

$\pm 3$
$+8$ $\pm 2 \%$

*O - Film Removed by Ultrasonic Treatment

* L Residual film Removed sy fcid Dissolution

* T - Total Film removed by Acid Dissolution 


\section{DEATSPEV}

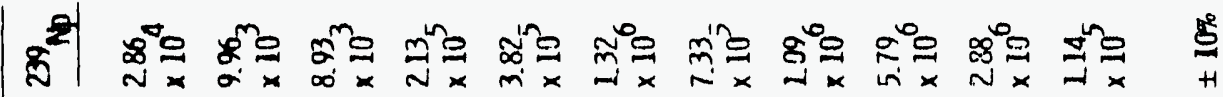

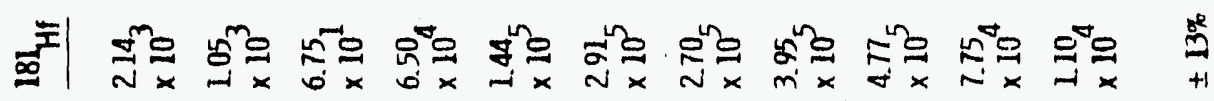

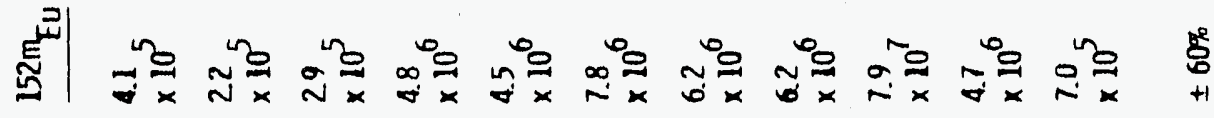

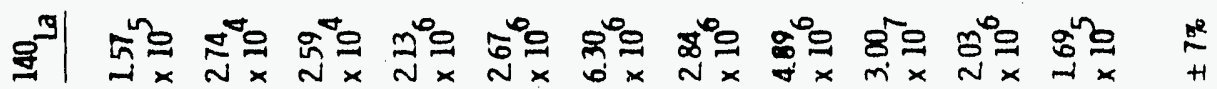

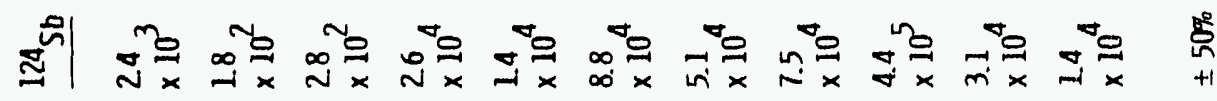

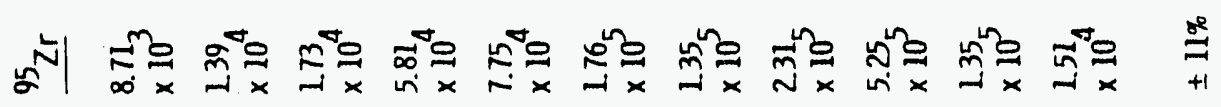

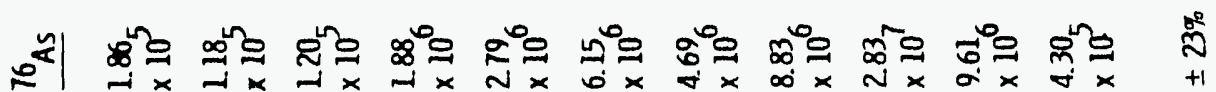

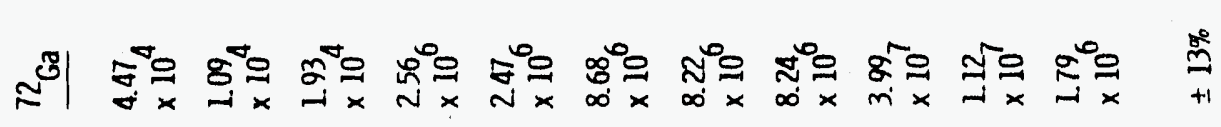

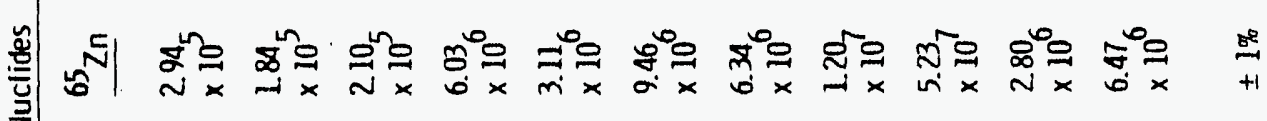

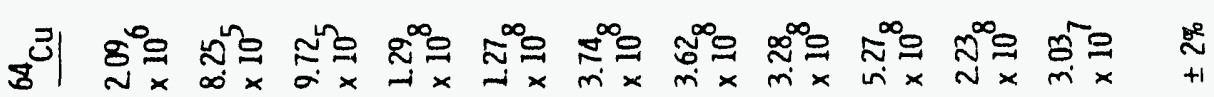

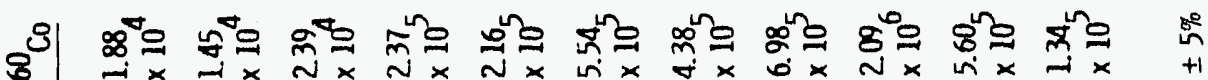

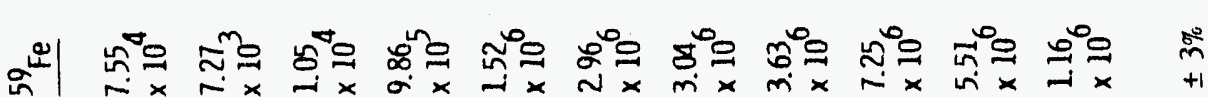

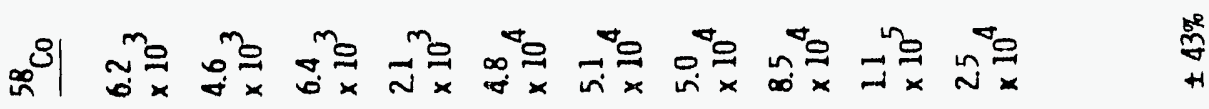

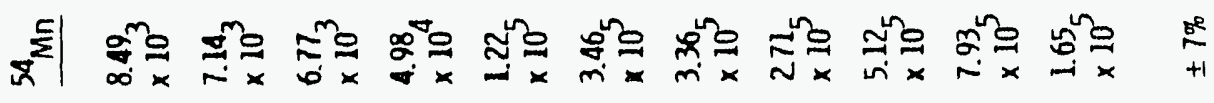

ज|

虫

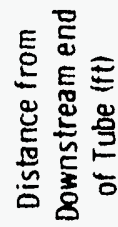

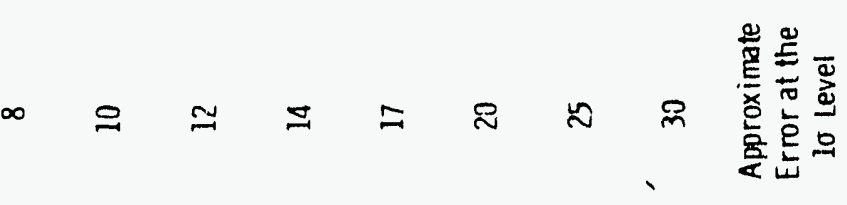




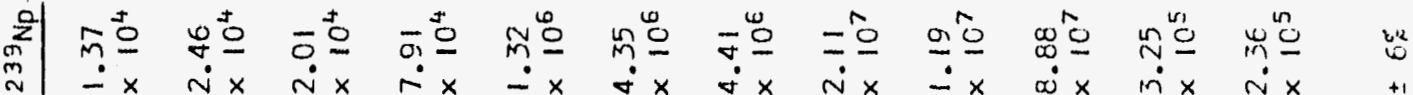

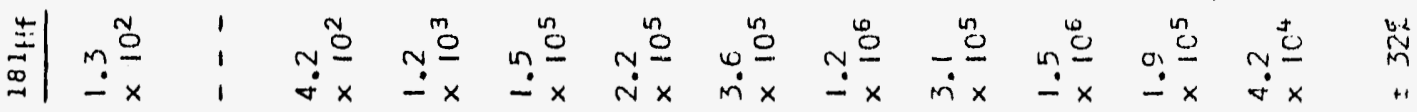

嵌|

嗬

点

点

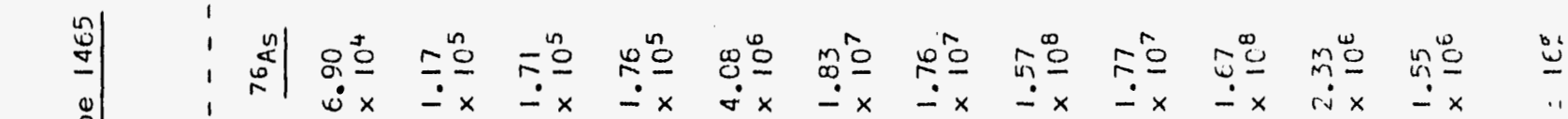

兽|

点|

矛 잉

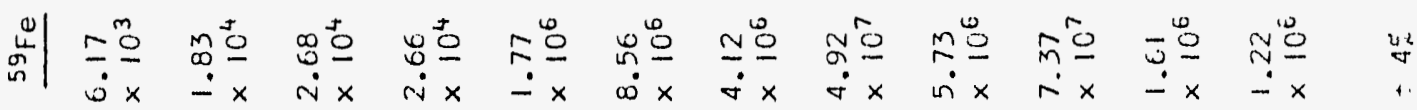
崩

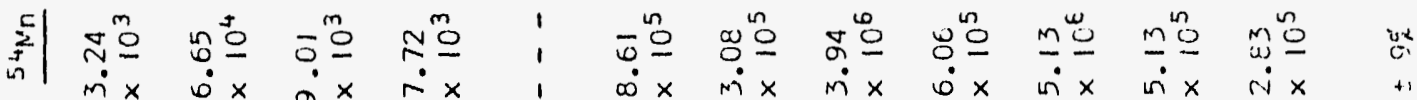
总 1 : 版

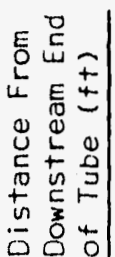




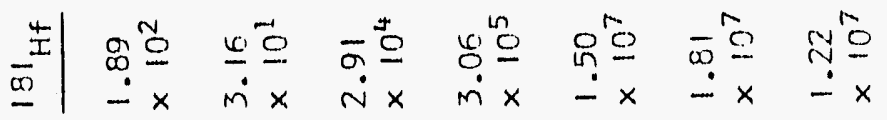

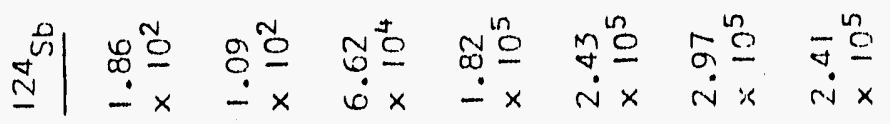

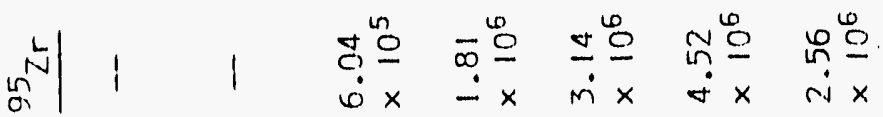

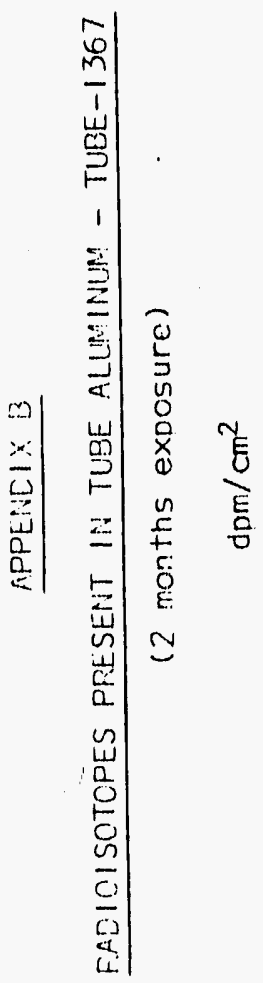

告|

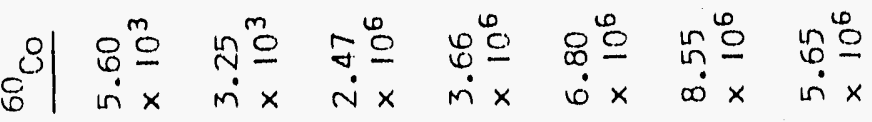

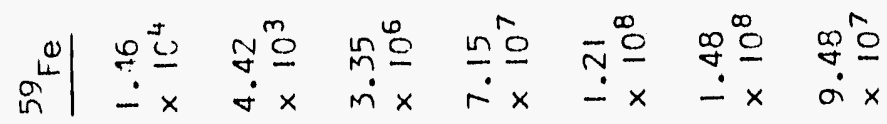

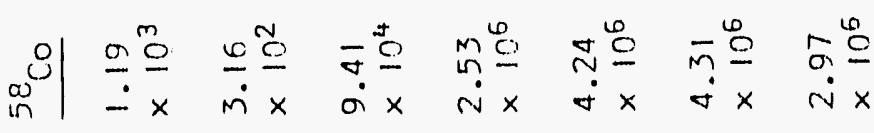

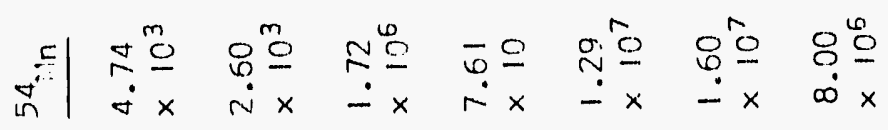

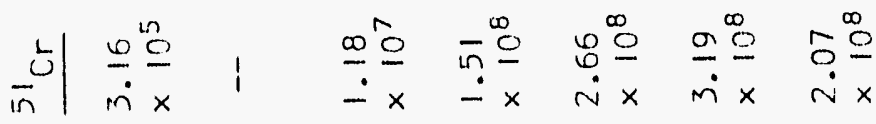

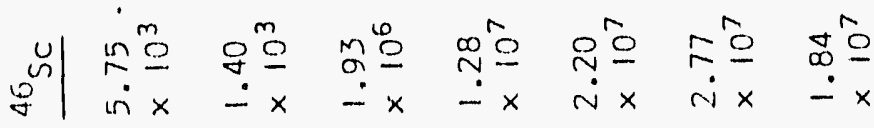

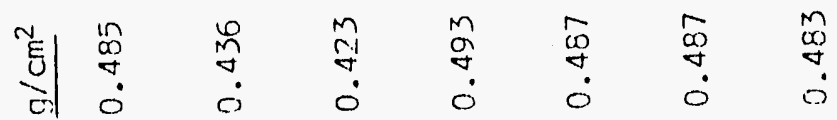

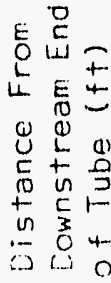




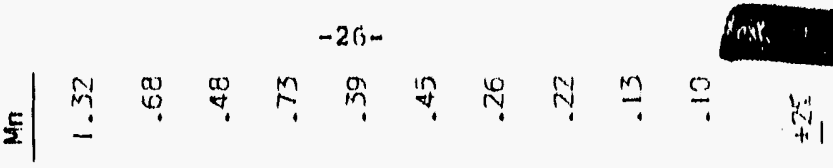

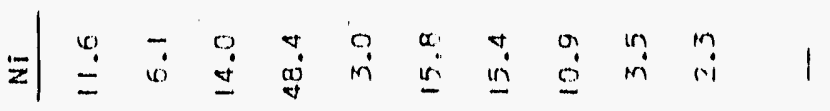

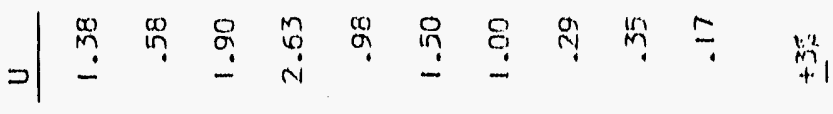

峲管

త|

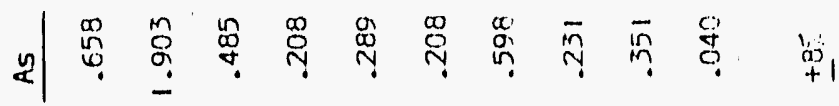

ภำ

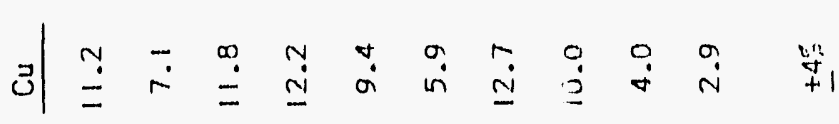

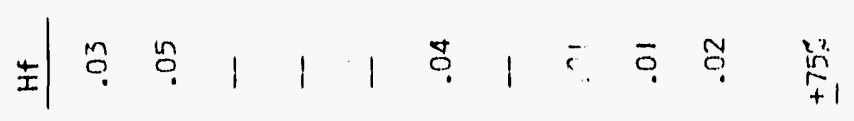

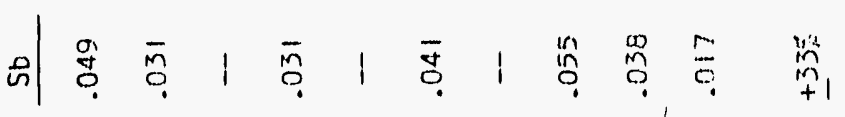

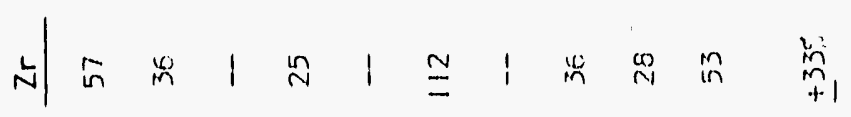

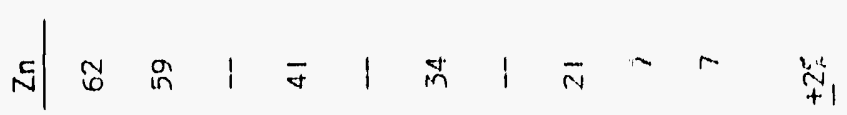

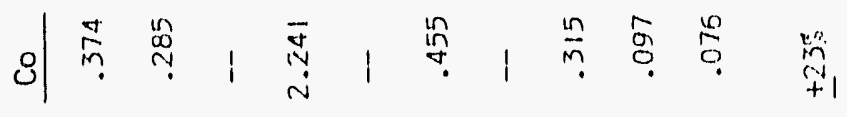

山|山

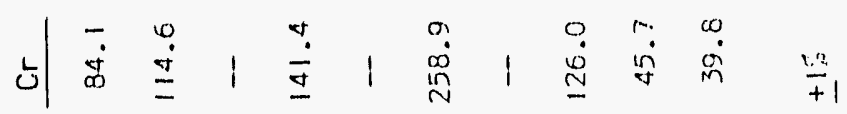

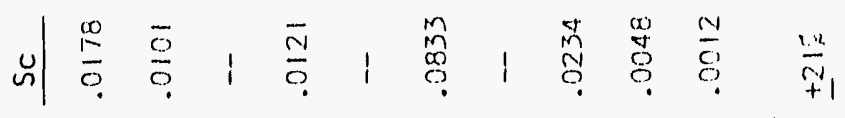

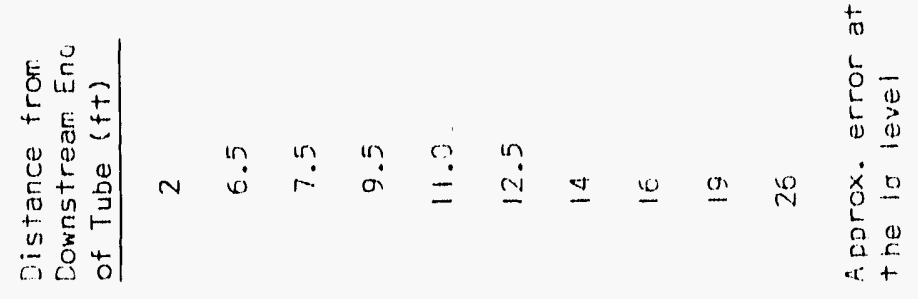


APPENCIX C-2

IIIERT ELEMENTS PRESENT IN SURFACE FILM - TUBE-1370

(10 months exposure)

$$
\mu \mathrm{g} / \mathrm{cm}^{2}
$$

Distance From

Downstream End

of Tube $(f t)$

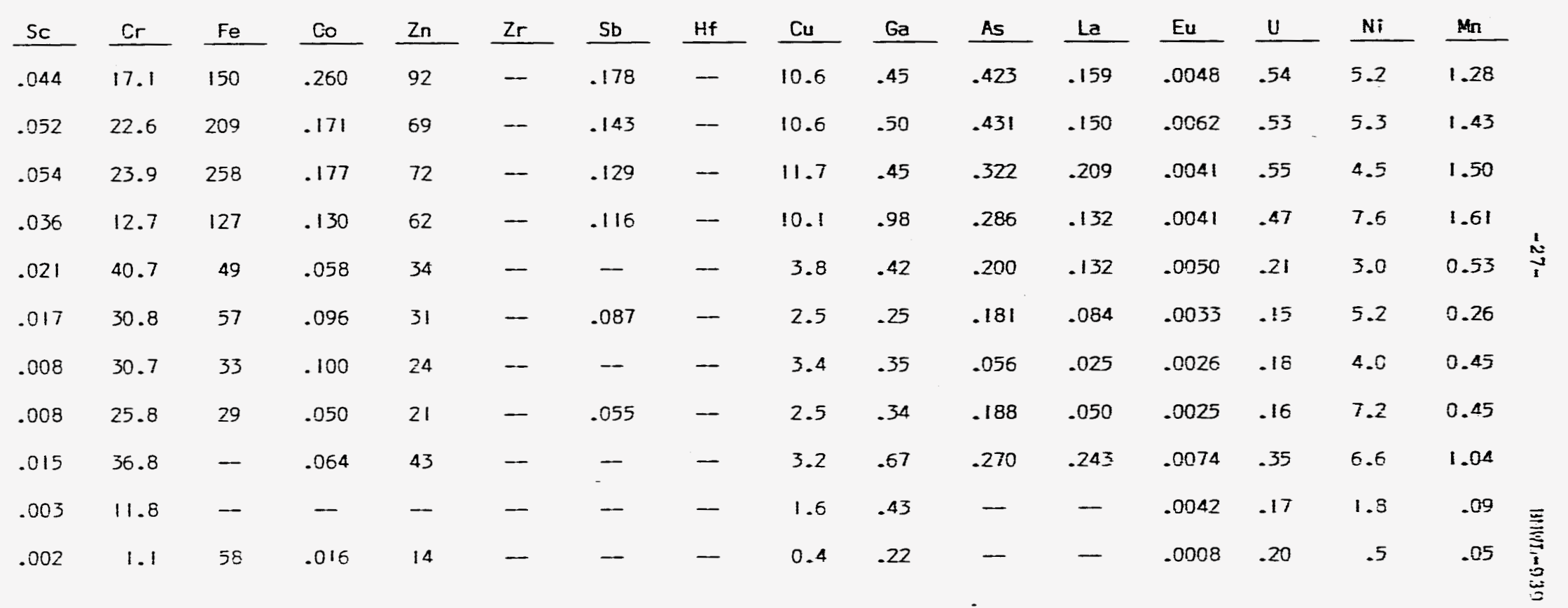

Aporox. Error

at the la level

$\pm 19= \pm$

$+12 \%$

$\pm 13 \% \quad+1 \%$

- วदू

$4 \% \quad 17$ 
APPENDIX C-3

INERT ELEMENTS PRESENT IN SURFACE FILM - TUBE-1465

(38 months exposure)

$\mu \mathrm{g} / \mathrm{cm}^{2}$

Distance From

Downstream End

of Tube $(\mathrm{ft})$

$\frac{\mathrm{Sc}}{0.15} \frac{\mathrm{Cr}}{58.3} \frac{\mathrm{Fe}}{825} \frac{\mathrm{Co}}{0.25} \frac{\mathrm{Zn}}{143}$

- - - - - ELEMENT - - - - -

1

$\begin{array}{lll}0.15 & 58.3 & 825 \\ 0.18 & 80.1 & 1133\end{array}$

$\begin{array}{lllll}0.18 & 80.1 & 1133 & 0.28 & 166\end{array}$

$\frac{\mathrm{Zr}}{13.1} \frac{\mathrm{Sb}}{.126}$

hif

$\frac{\mathrm{Cu}}{13.6} \quad \mathrm{Ga}$

As

La

$\frac{\mathrm{Eu}}{.0115} \frac{\mathrm{U}}{.83} \frac{\mathrm{Ni}}{11.5} \frac{\mathrm{Mn}}{3.21}$

2

$\begin{array}{lllll}0.12 & 89.6 & 2660 & 0.47 & 234\end{array}$

$13.7 \quad .102$

.07

$\begin{array}{lll}15.7 \quad 1.18 & .320\end{array}$

$\begin{array}{lllll}.693 & .0129 & 1.03 & 2.9 & 4.69\end{array}$

4

$\begin{array}{lllll}0.33 & 101.0 & 893 & 0.44 & 215\end{array}$

$23.2 \quad .167$

.16

$20.2 \quad 1.40 \quad 1.42$

$\begin{array}{lll}.836 & .0161 \quad 1.31\end{array}$

$2.6 \quad 5.56$

6

$\begin{array}{lllll}0.12 & 46.1 & 374 & .17 & 109\end{array}$

$24.2 \quad .105$

$\begin{array}{llll}19.9 & 1.09 \quad .804 & 1.1\end{array}$

$.0161 \quad 1.31$

- 3.35 心

8

0.13

$54.4 \quad 199$

.3381

$\begin{array}{lllll}0.02 & 41.8 \quad 111 \quad-- & 41\end{array}$

$19.5 \quad .034$

.01

$12.4 \quad 1.24 \quad .331$

$\begin{array}{lllll}.290 & .0071 & 1.04 \quad-\quad 1.51\end{array}$

12

$$
-
$$

0.02

$$
\text { -- - }
$$$$
\text { -- } \quad-
$$

$17.1 \quad-$

.08

$-$

$\begin{array}{lll}5.9 & 1.18 \quad .384\end{array}$

$\begin{array}{lll}3.3 & 0.95 \quad .418\end{array}$

$.543 \quad .0104 \quad 0.85$

$$
\text { - } 1.51
$$$$
5.4 \quad 1.70
$$$$
\text { - }
$$

$\begin{array}{lll}5.5 & 1.39 \quad .918\end{array}$

.205

0.50

$5.0 \quad 1.09$

17

0.02

$4 \mathrm{i} .7 \quad 24$

$\begin{array}{lll}0.05 & 23.8 & 87\end{array}$

$5.0 \quad .020$

$-$

3.91.

14.12 .04

20

0.02

.10

- $\quad-$

25

30

Approx. Error

at the lo

$\begin{array}{rrr}2.5 & 37 \\ -\quad 1.2 & 20 \quad-\end{array}$ 


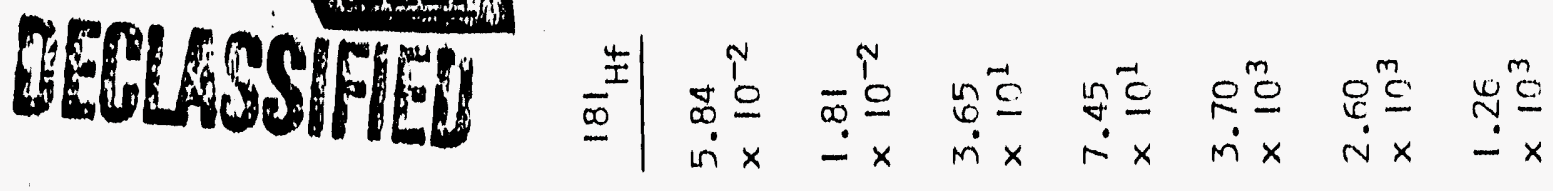

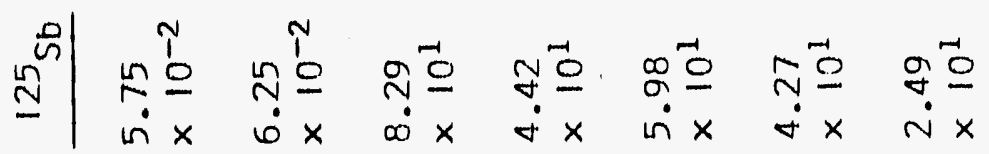

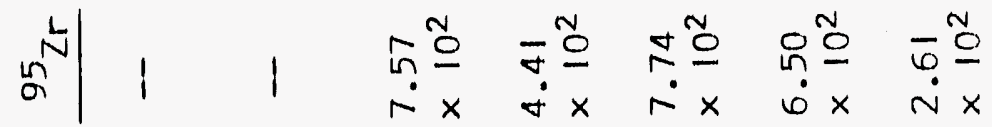

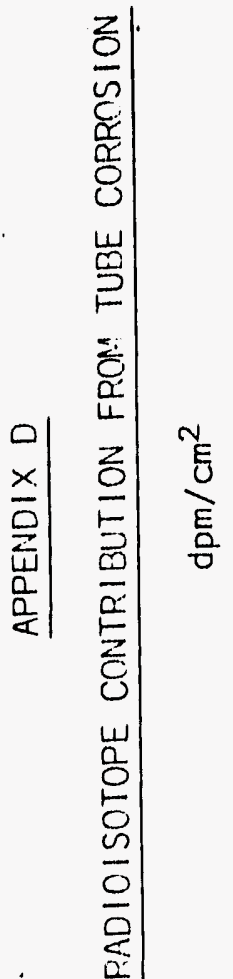

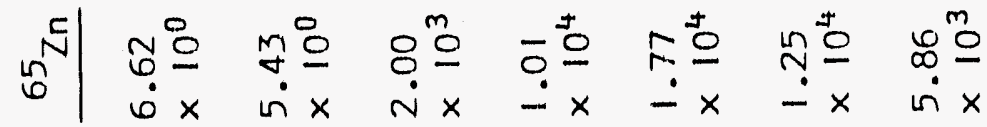

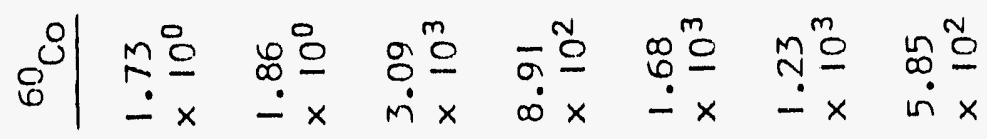

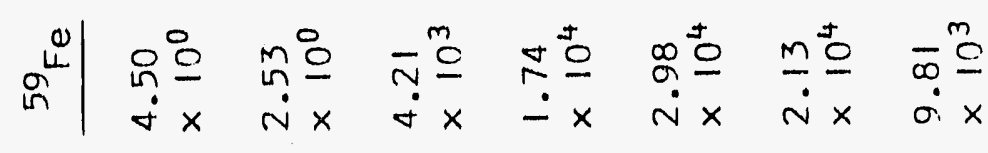

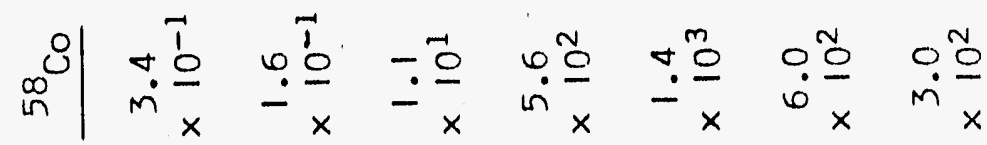

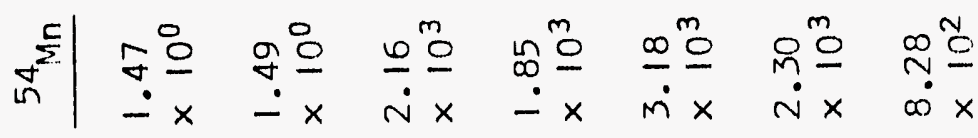

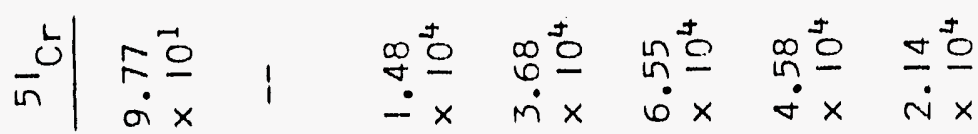

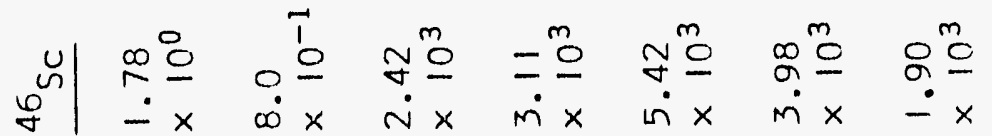

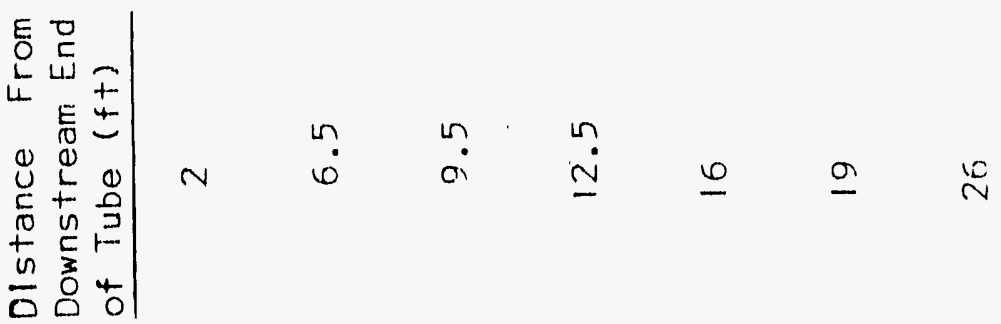




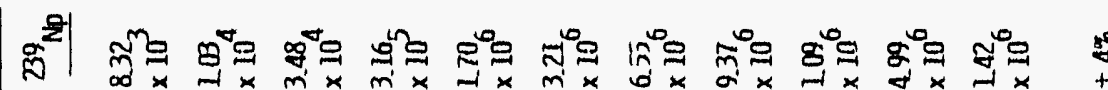

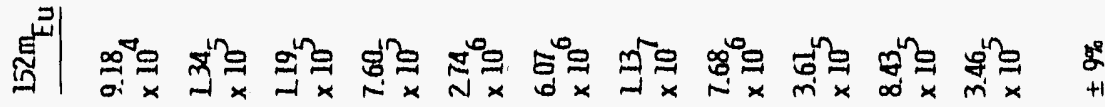
ఫ

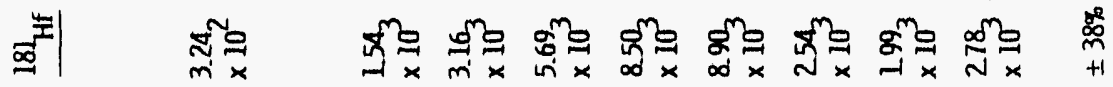
華|

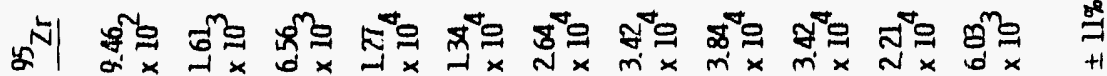

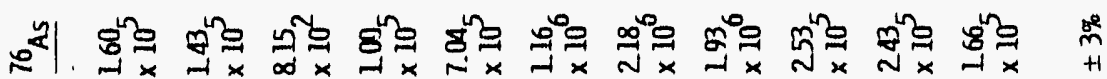

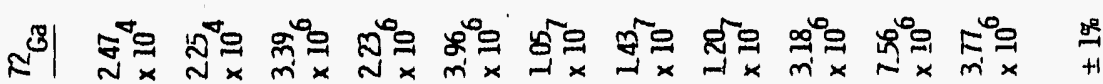

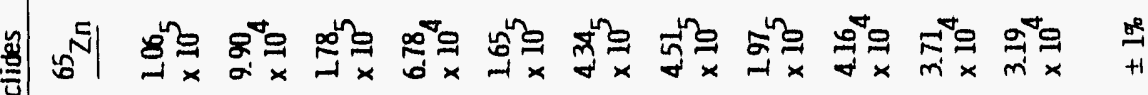

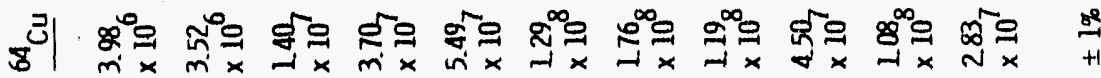

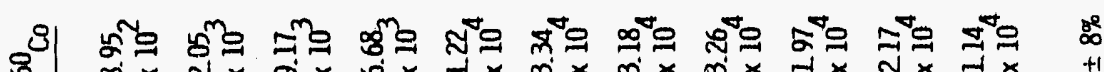
峛 融

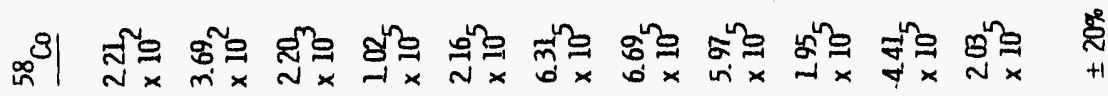

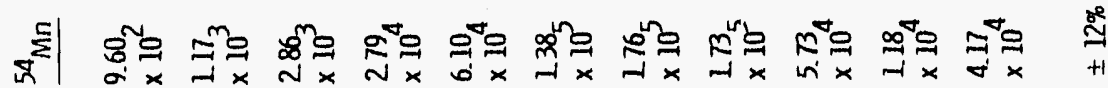

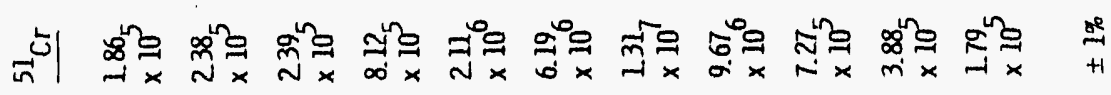

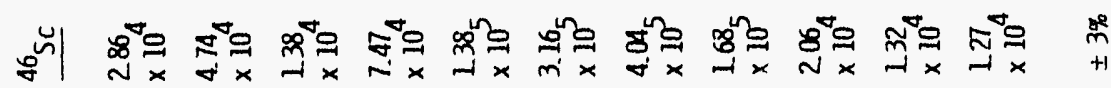

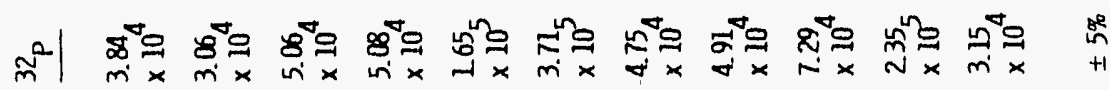

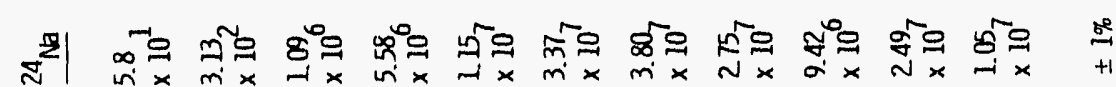

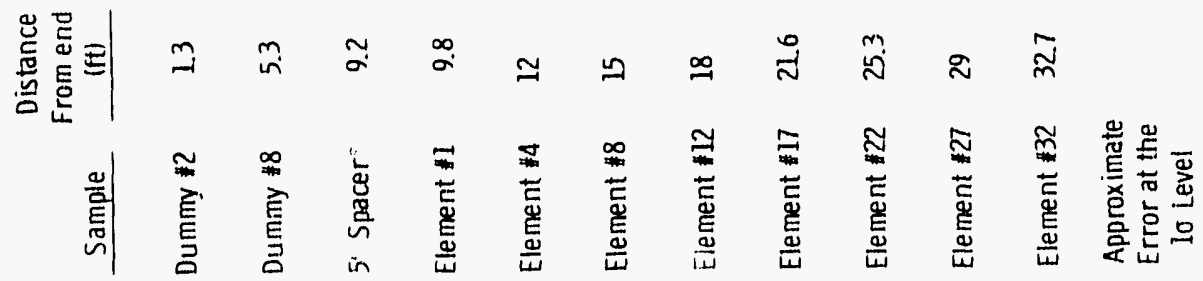

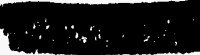




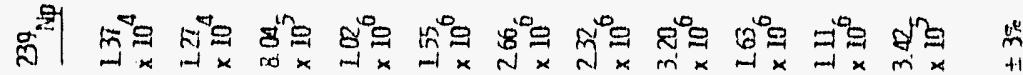

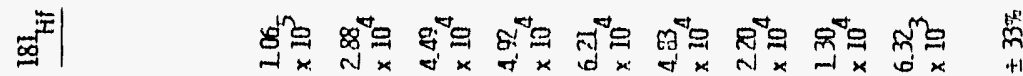

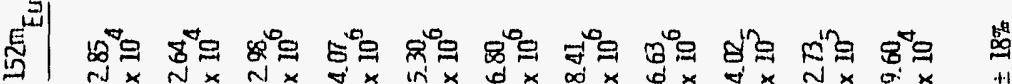

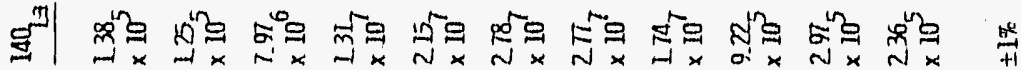

纱

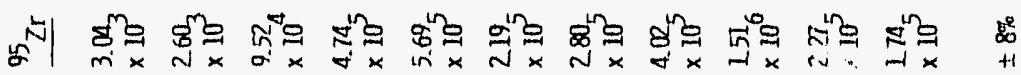

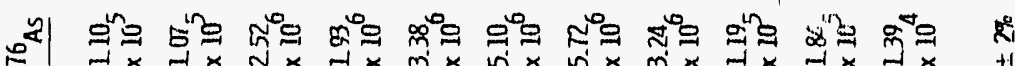

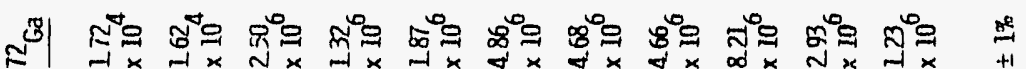

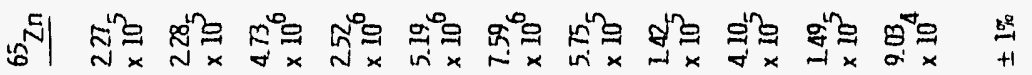

.

政

s)

嵌

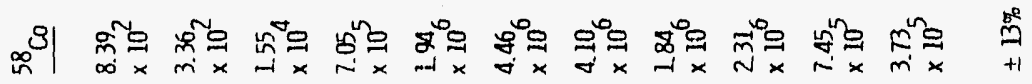

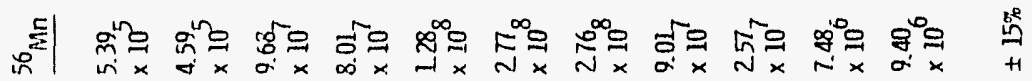

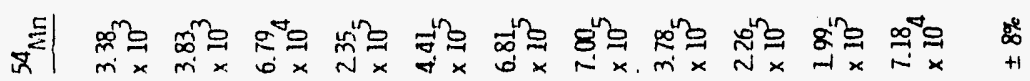

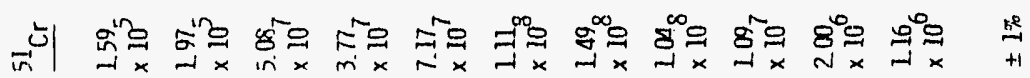

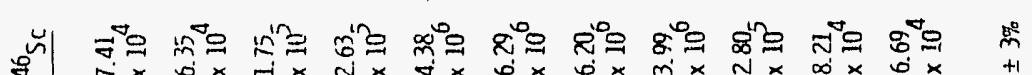

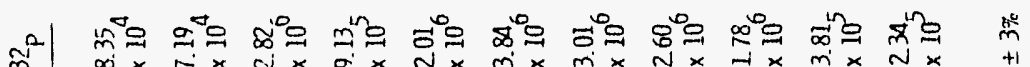

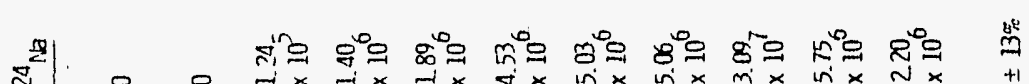

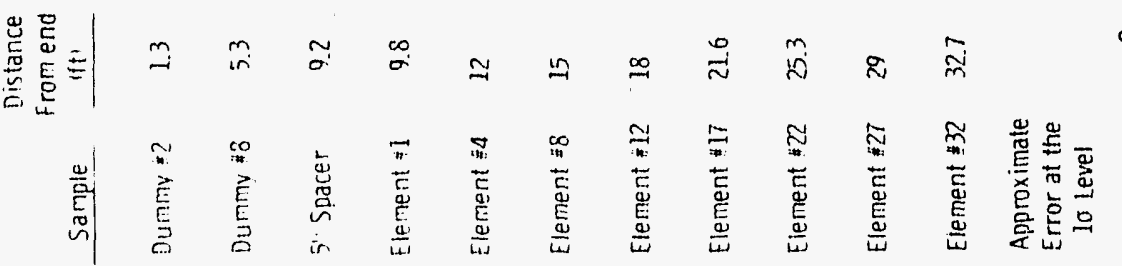


APPENDIXE-3

RADIOISOTOPES PRESENT ON FUEL ELEMENT FILM - 0770160 DAYS EXPOSURE

$\mathrm{dpm} / \mathrm{cm}^{2}$

Sample

\begin{tabular}{|c|c|c|c|c|c|c|c|c|c|c|c|c|c|c|c|c|c|c|}
\hline Immy $\# 1$ & 0.75 & 0 & $\begin{array}{l}283_{5} \\
\times 10^{5}\end{array}$ & $\begin{array}{l}1.05 \\
\times 10^{5}\end{array}$ & $\begin{array}{l}429 \\
\times 10^{4}\end{array}$ & $\begin{array}{l}282 \\
\times 10^{3}\end{array}$ & $\begin{array}{l}271_{3} \\
\times 10^{3}\end{array}$ & $\begin{array}{l}172 \\
\times 10^{4}\end{array}$ & $\begin{array}{l}4.47 \\
\times 10^{3}\end{array}$ & $\begin{array}{l}228 \\
\times 10^{6}\end{array}$ & $\begin{array}{l}3.18_{5} \\
\times 10^{5}\end{array}$ & $\begin{array}{l}26 \mathrm{I}^{4} \\
\times 10^{4}\end{array}$ & $\begin{array}{l}3.25_{5} \\
\times 10^{5}\end{array}$ & $\begin{array}{l}3.18 \\
\times 10^{3}\end{array}$ & $\begin{array}{l}6.98 \\
\times 10^{1}\end{array}$ & $\begin{array}{l}162_{5} \\
\times 10^{5}\end{array}$ & $\begin{array}{l}172 \\
\times 10^{2}\end{array}$ & $\begin{array}{l}97 \\
10^{4}\end{array}$ \\
\hline Immy *3 & 2 & 0 & $\begin{array}{l}268 \\
\times 10^{5}\end{array}$ & $\begin{array}{l}1.18 \\
\times 10^{5}\end{array}$ & $\begin{array}{r}6.95 \\
\times 10^{4}\end{array}$ & $\begin{array}{l}262_{3} \\
\times 10^{3}\end{array}$ & $\begin{array}{l}286 \\
\times 10^{3}\end{array}$ & $\begin{array}{l}1 \pi_{4} \\
\times 10^{4}\end{array}$ & $\begin{array}{l}430 \\
\times 10^{3}\end{array}$ & $\begin{array}{l}295 \\
\times 10^{6}\end{array}$ & $\begin{array}{l}3.45 \\
\times 10^{5}\end{array}$ & $\begin{array}{l}3.03 \\
\times 10^{4}\end{array}$ & $\begin{array}{l}4.15 \\
\times 10^{5}\end{array}$ & $\begin{array}{l}3.38 \\
\times 10^{3}\end{array}$ & $\begin{array}{l}1.75 \\
\times 10^{2}\end{array}$ & $\begin{array}{l}200 \\
\times 10^{5}\end{array}$ & & $\begin{array}{l}.16^{4} \\
10^{4}\end{array}$ \\
\hline mmy $* 5$ & 3.25 & 0 & $\begin{array}{l}3.94 \\
\times 10^{5}\end{array}$ & $\begin{array}{l}\mathrm{I} .25 \\
\times 10^{5}\end{array}$ & $\begin{array}{l}248_{5} \\
\times 10^{5}\end{array}$ & $\begin{array}{l}188 \\
\times 10^{3}\end{array}$ & $\begin{array}{l}241_{3} \\
\times 10^{3}\end{array}$ & $\begin{array}{l}162 \\
\times 10^{4}\end{array}$ & $\begin{array}{l}3.65 \\
\times 10^{3}\end{array}$ & $\begin{array}{l}3.30 \\
\times 10^{6}\end{array}$ & $\begin{array}{l}5.27 \\
\times 10^{5}\end{array}$ & $\begin{array}{l}4.099 \\
\times 10^{4}\end{array}$ & $\begin{array}{l}5.35 \\
\times 10^{5}\end{array}$ & $\begin{array}{l}284 \\
\times 10^{3}\end{array}$ & $\begin{array}{l}20{ }_{2} \\
\times 10^{2}\end{array}$ & $\begin{array}{l}1.97 \\
\times 10^{5}\end{array}$ & & $\begin{array}{l}.00 \\
10^{4}\end{array}$ \\
\hline mmy ${ }^{*} 7$ & 4.75 & 0 & $\begin{array}{l}3.91_{5} \\
\times 10^{5}\end{array}$ & $\begin{array}{l}128 \\
\times 10^{5}\end{array}$ & $\begin{array}{l}3.67_{5} \\
\times 10^{5}\end{array}$ & $\begin{array}{l}3.54_{3} \\
\times 10^{3}\end{array}$ & $\begin{array}{l}3.15 \\
\times 10^{3}\end{array}$ & $\begin{array}{l}272 \\
\times 10^{4}\end{array}$ & $\begin{array}{l}3.86 \\
\times 10^{3}\end{array}$ & $\begin{array}{l}275 \\
\times 10^{6}\end{array}$ & $\begin{array}{l}6.3_{5} \\
\times 10^{5}\end{array}$ & $\begin{array}{l}4.73 \\
\times 10^{4}\end{array}$ & $\frac{177_{5}}{10^{5}}$ & $\begin{array}{l}5.58 \\
\times 10^{3}\end{array}$ & $\begin{array}{l}4.3 L_{2} \\
\times 10^{2}\end{array}$ & $\begin{array}{l}167 \\
\times 10^{5}\end{array}$ & & $9 I_{4}$ \\
\hline Immy $\# 9$ & 6 & $\begin{array}{l}1.4 l_{3} \\
\times 10^{2}\end{array}$ & $\begin{array}{l}5.10_{5} \\
\times 10^{5}\end{array}$ & $\begin{array}{l}1335 \\
\times 10^{5}\end{array}$ & $\begin{array}{l}282_{5} \\
\times 10^{5}\end{array}$ & $\begin{array}{l}279 \\
\times 10^{4}\end{array}$ & $\begin{array}{l}269 \\
\times 10^{3}\end{array}$ & $\begin{array}{l}1.99 \\
\times 10^{4}\end{array}$ & $\begin{array}{l}4.62 \\
\times 10^{3}\end{array}$ & $\begin{array}{l}3.54 \\
\times 10^{6}\end{array}$ & $\begin{array}{l}6.06 \\
\times 10^{5}\end{array}$ & $\begin{array}{l}6.36 \\
\times 10^{4}\end{array}$ & $\begin{array}{l}5.52 \\
\times 10^{5}\end{array}$ & $\begin{array}{l}3.35 \\
\times 10^{3}\end{array}$ & $\begin{array}{l}3.96 \\
\times 10^{2}\end{array}$ & $\begin{array}{l}235 \\
\times 10^{\circ}\end{array}$ & & $\begin{array}{l}-41_{4} \\
10^{4}\end{array}$ \\
\hline ement 1 & 11.5 & $3.63{ }_{6}$ & $\begin{array}{l}1277 \\
\times 10^{7}\end{array}$ & $\begin{array}{l}116 \\
\times 10\end{array}$ & $\begin{array}{l}141_{8} \\
\times 10^{2}\end{array}$ & $\begin{array}{l}9.97 \\
\times 10^{5}\end{array}$ & $\begin{array}{l}6.60 \\
\times 10^{6}\end{array}$ & $\begin{array}{l}4.72 \\
\times 10^{6}\end{array}$ & $\begin{array}{l}3.16_{5} \\
\times 10^{5}\end{array}$ & $\begin{array}{l}3.42 \\
\times 10^{8}\end{array}$ & $\begin{array}{l}200 \\
\times 10^{7}\end{array}$ & $\begin{array}{l}7.49 \\
\times 10^{6}\end{array}$ & $\begin{array}{l}239 \\
\times 10^{7}\end{array}$ & $\begin{array}{l}185 \\
\times 10^{5}\end{array}$ & $\begin{array}{l}2 \mathrm{Il}_{5} \\
\times 10^{5}\end{array}$ & $\begin{array}{l}3.93 \\
\times 10^{7}\end{array}$ & $\begin{array}{l}3.09_{5} \\
\times 10^{5}\end{array}$ & $10^{6}$ \\
\hline ement $\# 4$ & 13.25 & $\begin{array}{l}7.38 \\
\times 10^{6}\end{array}$ & $\begin{array}{l}1947 \\
\times 10\end{array}$ & $\begin{array}{l}4.91 \\
\times 10^{6}\end{array}$ & $\begin{array}{l}6.31 \\
\times 10\end{array}$ & $\begin{array}{l}131_{6} \\
\times 10^{6}\end{array}$ & $\begin{array}{l}1597 \\
\times 10^{7}\end{array}$ & $\begin{array}{l}3.49 \\
\times 10^{6}\end{array}$ & $\begin{array}{l}23_{5} \\
\times 10^{5}\end{array}$ & $\begin{array}{l}8.19 \\
\times 10^{8}\end{array}$ & $\begin{array}{l}1.92 \\
\times 10^{2}\end{array}$ & $\begin{array}{l}1 \pi_{7} \\
\times 10^{2}\end{array}$ & $\begin{array}{l}2177 \\
\times 10^{7}\end{array}$ & $\begin{array}{l}5.18 \\
\times 10^{4}\end{array}$ & $\begin{array}{r}135_{5} \\
\times 10^{5}\end{array}$ & $\begin{array}{l}1427 \\
\times 10^{7}\end{array}$ & $\begin{array}{l}267_{5} \\
\times 10^{5}\end{array}$ & $\begin{array}{l}666_{6}^{6} \\
10^{\circ}\end{array}$ \\
\hline ement \#8 & 15.5 & $\begin{array}{l}1.577 \\
\times 10^{7}\end{array}$ & $\begin{array}{l}4.88 \\
\times 10\end{array}$ & $\begin{array}{l}5.60 \\
\times 10^{6}\end{array}$ & $\begin{array}{l}6.62 \\
\times 10^{7}\end{array}$ & $\begin{array}{l}4.066 \\
\times 10^{6}\end{array}$ & $\begin{array}{l}3.72 \\
\times 10^{7}\end{array}$ & $\begin{array}{l}5.34 \\
\times 10^{6}\end{array}$ & $\begin{array}{l}168 \\
\times 10^{6}\end{array}$ & $\begin{array}{l}2.149 \\
\times 10^{9}\end{array}$ & $\begin{array}{l}3.15 \\
\times 10^{7}\end{array}$ & $\begin{array}{l}279 \\
\times 10^{7}\end{array}$ & $\begin{array}{l}3.707 \\
\times 10\end{array}$ & & $\begin{array}{l}197_{5} \\
\times 10^{5}\end{array}$ & $\begin{array}{l}190 \\
\times 10\end{array}$ & $\begin{array}{l}5.28 \\
\times 10^{5}\end{array}$ & $\begin{array}{l}86_{6} \\
10^{6}\end{array}$ \\
\hline ment $\# 13$ & 18 & $\begin{array}{l}9.89 \\
\times 10^{6}\end{array}$ & $\begin{array}{l}268 \\
\times 10^{7}\end{array}$ & $\begin{array}{r}7.90 \\
\times 10^{6}\end{array}$ & $\begin{array}{l}9.277 \\
\times 10^{7}\end{array}$ & $\begin{array}{l}228 \\
\times 10^{6}\end{array}$ & $\begin{array}{l}229 \\
\times 10\end{array}$ & $\begin{array}{l}5.65 \\
\times 10^{6}\end{array}$ & $\begin{array}{l}278 \\
\times 10^{5}\end{array}$ & $\begin{array}{l}1159 \\
\times 10^{9}\end{array}$ & $\begin{array}{l}1717 \\
\times 10\end{array}$ & $\begin{array}{l}171_{7} \\
\times 10^{7}\end{array}$ & $\begin{array}{l}297 \\
\times 10^{7}\end{array}$ & $\begin{array}{l}130_{5} \\
\times 10^{5}\end{array}$ & $\begin{array}{l}137_{5} \\
\times 10^{2}\end{array}$ & $\begin{array}{l}2 \pi \\
\times 10^{7}\end{array}$ & $\begin{array}{l}3.96_{5} \\
\times 10^{5}\end{array}$ & $\begin{array}{l}7.18 \\
\times 10^{6}\end{array}$ \\
\hline ement $: 20$ & 22 & & $\begin{array}{l}7.77 \\
\times 10^{6}\end{array}$ & $\begin{array}{l}7.81 \\
\times 10^{6}\end{array}$ & $\begin{array}{l}1 B_{8} \\
\times 10^{8}\end{array}$ & $\begin{array}{l}6.23_{5} \\
\times 10^{5}\end{array}$ & 4.376 & $\begin{array}{l}4.12 \\
\times 10^{6}\end{array}$ & $\begin{array}{l}8.08 \\
\times 10^{4}\end{array}$ & $\begin{array}{l}4.18 \\
\times 10^{8}\end{array}$ & $\begin{array}{l}4.30 \\
\times 10^{6}\end{array}$ & $\begin{array}{l}107_{7} \\
\times 10^{T}\end{array}$ & $\begin{array}{l}163 \\
\times 10^{7}\end{array}$ & $\begin{array}{l}270_{5} \\
\times 10^{5}\end{array}$ & $\begin{array}{l}1 \pi_{5} \\
\times 10^{2}\end{array}$ & $\begin{array}{l}220 \\
\times 10^{7}\end{array}$ & $\begin{array}{l}179 \\
\times 10^{5}\end{array}$ & $\begin{array}{l}4.12 \\
\times 10^{6}\end{array}$ \\
\hline lement \#27 & 26 & $231_{7}$ & $\begin{array}{l}6.39 \\
\times 10^{6}\end{array}$ & $\begin{array}{l}247_{5} \\
\times 10^{5}\end{array}$ & $4.72_{6}$ & $\begin{array}{l}293 \\
\times 10^{5}\end{array}$ & $4.35{ }_{6}$ & $\begin{array}{r}5.72 \\
\times 10^{5}\end{array}$ & $\begin{array}{r}4.19 \\
\times 10^{4}\end{array}$ & $\begin{array}{l}1.01 \\
\times 10^{8}\end{array}$ & $\begin{array}{l}6.36 \\
\times 10^{5}\end{array}$ & $\begin{array}{l}127 \\
\times 10^{7}\end{array}$ & $\begin{array}{l}237 \\
\times 10^{6}\end{array}$ & $\begin{array}{l}3.2 \pi_{5} \\
\times 10^{5}\end{array}$ & $\begin{array}{l}3.61 \\
\times 10^{4}\end{array}$ & $\begin{array}{l}7.09 \\
\times 10^{5}\end{array}$ & $\begin{array}{l}6.95 \\
\times 10^{4}\end{array}$ & $\begin{array}{l}3.23 \\
\times 10^{6}\end{array}$ \\
\hline ment & 29.7 & $\begin{array}{l}2697 \\
\times 10^{7}\end{array}$ & $\begin{array}{l}2311^{6} \\
\times 10^{6}\end{array}$ & $\begin{array}{l}7.46 \\
\times 10^{4}\end{array}$ & $\begin{array}{l}159 \\
\times 10^{6}\end{array}$ & $\begin{array}{l}5.266_{5} \\
\times 10^{2}\end{array}$ & $\begin{array}{l}4.72 \\
\times 10^{6}\end{array}$ & $\begin{array}{l}4.01_{5} \\
\times 10^{5}\end{array}$ & $\begin{array}{l}208_{5} \\
\times 10^{3}\end{array}$ & $\begin{array}{l}6.08 \\
\times 10\end{array}$ & $\begin{array}{l}3.32 \\
\times 10^{5}\end{array}$ & $\begin{array}{l}128 \\
\times 10\end{array}$ & $\begin{array}{l}9.34_{5} \\
\times 10^{5}\end{array}$ & $\begin{array}{l}191_{5} \\
\times 10^{5}\end{array}$ & $\begin{array}{l}199 \\
\times 10^{4}\end{array}$ & $\begin{array}{l}7.60_{5} \\
\times 10^{5}\end{array}$ & $\begin{array}{l}7.12 \\
\times 10^{4}\end{array}$ & $7.14_{5}$ \\
\hline $\begin{array}{l}\text { ror at the } \\
\text { of Level }\end{array}$ & & $1 \%$ & $2 \%$ & $\pm 3 \%$ & $1 \%$ & $\pm 8 \%$ & $16 \%$ & $\pm 3 \%$ & $\pm 6 \%$ & $\pm 1 \%$ & $\pm 3 \%$ & $\pm 1 \%$ & \pm 2 & $\pm 4 \xi_{0}$ & $\pm 26 \%$ & $\pm 1 \%$ & $\pm 30 \%$ & $c x$ \\
\hline
\end{tabular}




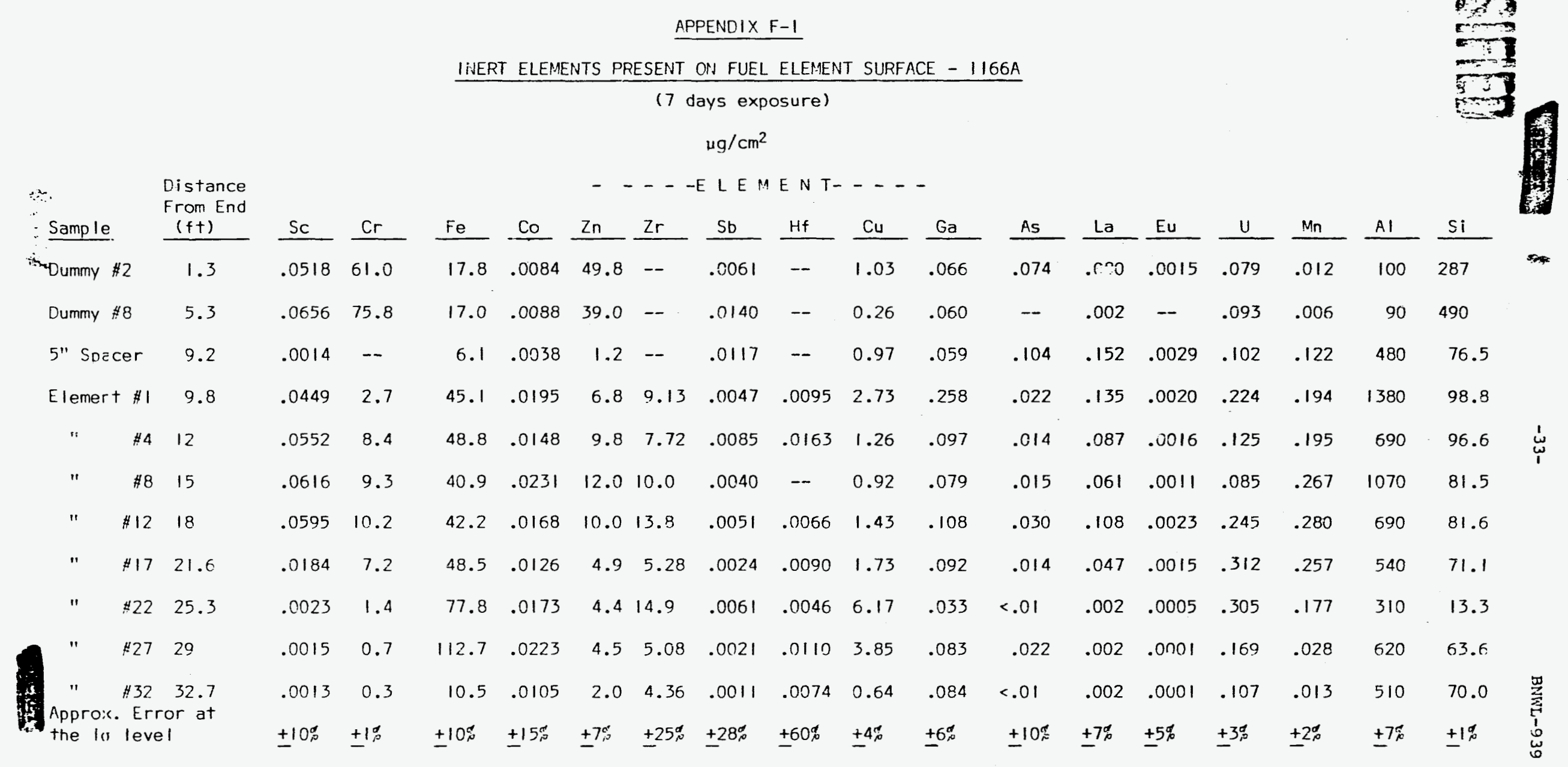




\section{APPENDIX F-2}

INERT ELEMENTS PRESENT ON FUEL ELEMENT FILM - $1166 \mathrm{~B}$

( 3 ó days exposure)

$$
\mu \mathrm{n} / \mathrm{cm}^{?}
$$

$\ldots$ - - E LE $\because$ EN T- - . -

\begin{tabular}{|c|c|c|c|c|c|c|c|c|c|c|c|c|c|c|c|c|c|c|c|c|}
\hline \multicolumn{2}{|l|}{ Samp le } & $(f t)^{*}$ & Sc & $\mathrm{Cr}$ & $\mathrm{Fe}$ & $\mathrm{Co}$ & $\underline{Z n}$ & $\mathrm{Zr}$ & Sb & $\mathrm{Hf}$ & $\mathrm{Cu}$ & $\mathrm{Ga}$ & As & La & Eu & $\underline{U}$ & $\mathrm{Ni}$ & Mn & A.1 & $\underline{\mathrm{Si}}$ \\
\hline Durnmy $\#$ & 42 & 1.3 & .064 & 34.3 & 141 & .063 & 37.0 & 4.7 & .0046 & .048 & 5.76 & .190 & .150 & .194 & .0036 & .166 & 1.0 & 2.79 & 820 & 36.5 \\
\hline Du nmy & 48 & 5.3 & .058 & 55.9 & 123 & .056 & 37.3 & 5.6 & .0032 & .098 & .54 & .027 & .060 & .032 & .0005 & .130 & .13 & .03 & 820 & 21.6 \\
\hline 5" Space & cer & 9.2 & .060 & 52.7 & 103 & .030 & 29.1 & 31 & .0162 & .029 & 5.07 & .212 & .105 & .121 & .0022 & .109 & .40 & .36 & 730 & 112.0 \\
\hline E!ement & $+\# 1$ & 9.8 & .141 & 29.5 & 192 & .031 & 23.3 & 29 & .0086 & .036 & 2.50 & .100 & .082 & .448 & .0054 & 1.32 & 20.1 & .35 & 310 & 82.6 \\
\hline$"$ & $\$ 4$ & 12 & .097 & 21.1 & 115 & .019 & 23.4 & 157 & .0450 & .053 & 2.73 & .071 & .134 & .438 & .0063 & 2.47 & 9.2 & .30 & 310 & 52.7 \\
\hline$"$ & $\# 8$ & 15 & .066 & 26.9 & 125 & .027 & 27.4 & 57 & -- & .063 & 3.16 & .115 & .132 & .357 & .0053 & 1.13 & 12.4 & .33 & 230 & 68.9 \\
\hline$"$ & $\# 12$ & 18 & .044 & 16.5 & 57.2 & .005 & 16.1 & 67 & -- & .028 & 4.76 & .093 & .102 & .285 & .0053 & 1.48 & 14.2 & .27 & 430 & 39.1 \\
\hline$"$ & $\$ 17$ & 21.6 & .039 & 3.0 & 63.3 & .001 & 11.3 & 172 & .0301 & .076 & 2.82 & .095 & .277 & .198 & .0048 & 2.69 & 5.0 & .14 & 310 & 48.8 \\
\hline$"$ & $\$ 22$ & 25.3 & .036 & 6.3 & 46.5 & .008 & 26.7 & -- & .0032 & .030 & 3.03 & .111 & .046 & .015 & .0005 & 1.95 & 8.2 & .15 & 640 & 43.5 \\
\hline$"$ & $\$ 27$ & 29 & .002 & 1.8 & 58.0 & .020 & 19.7 & 43 & .0115 & .017 & 2.01 & .077 & .048 & .011 & .0003 & .89 & 2.5 & .06 & 280 & 14.3 \\
\hline$"$ & $\$ 32$ & 32.7 & .002 & 1.2 & 18.1 & .010 & 14.9 & 103 & .0409 & .015 & 1.21 & .098 & .059 & .010 & .0004 & 1.20 & 8.5 & .06 & 340 & 15.3 \\
\hline
\end{tabular}

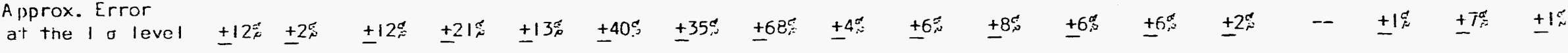

* Eistance From End 
APPENDIX F-3

INERT ELE' ENTSS PRESENT ON FUEL ELEMENT FILM - 0770

( 60 days exposure)

$$
\mathrm{\mu g} / \mathrm{cm}^{2}
$$

\section{$\ldots \ldots$..... E LE I I E N T _.......}

\begin{tabular}{|c|c|c|c|c|c|c|c|c|c|c|c|c|c|c|c|c|c|c|c|c|}
\hline Sample & & $(f t)^{*}$ & $\mathrm{Sc}$ & $\mathrm{Cr}$ & $\mathrm{Fe}$ & Co & $\mathrm{Zn}$ & $\mathrm{Zr}$ & Sb & $\mathrm{HF}$ & $\mathrm{Cu}$ & $\mathrm{Ga}$ & A.s & La & Eu & U & $\mathrm{iii}$ & $M n$ & Al & $\mathrm{Si}$ \\
\hline Dummy & $\# 1$ & .75 & .048 & 108 & 194 & .076 & 136 & 10.9 & .0318 & .118 & 8.19 & .354 & .382 & .254 & .0042 & .433 & 1.0 & 1.18 & -- & 340 \\
\hline$"$ & 43 & 2 & .051 & 133 & 206 & .071 & 141 & 10.1 & .0451 & .011 & 6.49 & .255 & .382 & .291 & .0046 & .421 & 1.4 & 1.15 & -- & 270 \\
\hline$"$ & $\$ 5$ & 3.25 & .059 & 323 & 177 & .066 & 220 & 10.6 & .0598 & .014 & 6.00 & .574 & .605 & .315 & .0054 & .543 & 1.0 & 1.27 & -- & 390 \\
\hline$"$ & $\$ 7$ & 4.75 & .049 & 346 & 142 & .043 & 233 & 8.6 & .0624 & .025 & 3.24 & .408 & .542 & .296 & .0046 & .524 & 0.9 & 0.93 & -- & 110 \\
\hline$"$ & $\# 9$ & 6 & .059 & 310 & 177 & .065 & 224 & 10.1 & .0562 & .009 & 4.38 & .673 & .564 & .356 & .0059 & .599 & 1.1 & 1.19 & -- & 340 \\
\hline lement & $+\# 1$ & 11.5 & .083 & 41.7 & 238 & .030 & 110 & 54.4 & -- & -- & 3.47 & .213 & .405 & .864 & .0117 & .969 & 38 & 1.62 & 1620 & 74 \\
\hline$"$ & $\# 4$ & 13.25 & .009 & 20.5 & 59.5 & .020 & 55 & 149 & .0521 & -- & 3.14 & .320 & .393 & .274 & .0045 & 1.706 & 64 & 1.44 & 2190 & 94 \\
\hline$"$ & $\$ 8$ & 15.5 & -- & 15.3 & 53.2 & -- & 18 & 289 & -- & -- & 5.33 & .436 & .422 & .235 & .0091 & 3.055 & 104 & 1.94 & 4200 & 55 \\
\hline$"$ & $\$ 13$ & 18 & -- & 21.1 & 3.0 & -- & 25 & 159 & -- & -- & 2.99 & .228 & .332 & .290 & .0081 & 2.076 & 58 & 1.05 & 1950 & 42 \\
\hline$"$ & $\$ 20$ & 22 & -- & 22.4 & 18.4 & .007 & 21 & 94 & -- & - & 2.62 & .145 & .142 & .263 & .0044 & 1.606 & 16 & .24 & 1020 & 25 \\
\hline$"$ & $\# 27$ & 26 & .002 & 6.2 & 34.8 & .013 & 4 & 198 & -- & -- & 1.07 & .217 & .208 & .475 & .0015 & 3.395 & 18 & .11 & 1220 & 20 \\
\hline$"$ & $\$ 34$ & 29.75 & .002 & 27.3 & 127 & .049 & 4 & 52 & -- & -- & 1.46 & .313 & .283 & .053 & .0005 & 1.008 & 54 & .83 & 1750 & 27 \\
\hline $\begin{array}{l}\text { Approx } \\
\text { at the }\end{array}$ & $\begin{array}{l}x \cdot E r \\
=10\end{array}$ & ir & $\pm 1 ? \%$ & $\pm 2_{j}^{c}$ & $\pm 15 \%$ & $\pm \mid \in ?$ & $\pm 14 \xi$ & \pm 25 & $\pm 30 \%$ & -- & \pm & \pm 4 & +5 & \pm 6 & $\pm 6 \%$ & $\pm 2 \%$ & -- & $\pm 1 \%$ & $\pm 7 \%$ & \pm \\
\hline
\end{tabular}

* Distance from End 


\section{APPENDIX G-I}

$\frac{\text { CALCULATED RES IDENCE TIME OF ELEMENTS - TUBE- } 1367}{(2 \text { months exposure })}$

(Days)

Distance

\section{$(f+)$}

\section{5}

12.5

16

19

26
Sc

9.4

5.0

9.8

5.2

3.6
$\mathrm{Cr}$

.86

1.1

2.6

.59

.02
$\underline{\mathrm{Fe}}$

6.7

3.8

10.8

.59

.02
Co

.47

.19

.30

.30

.53

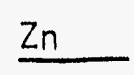

$\underline{2 r}$

37

22

36

12

3
Sb

1.9

1.6

.52

.17

.004

--

.36
$\underline{H f}$

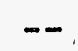

3.3

12.7

1.5

.5 
APPEIVIX G-2

CALCULATED PESIOENCE TII:E OF ELENENTS - TUBE-1370

( 10 months exposure)

(Days)

\begin{tabular}{|c|c|c|c|c|c|c|c|c|c|c|c|c|}
\hline $\begin{array}{c}\text { Distance } \\
(\mathrm{ft}) \\
\end{array}$ & Sc & $\mathrm{Cr}$ & $\mathrm{Fe}$ & Co & $\mathrm{Zn}$ & $\mathrm{Sb}$ & $\mathrm{Cu}$ & $\mathrm{Ga}$ & Eu & La & U & As \\
\hline 8 & 99 & 18 & $>149$ & 73 & 104 & 16 & * & 1.5 & * & * & 1.5 & * \\
\hline 10 & 22 & 1.6 & $>149$ & 55 & 39 & $\therefore$ & * & * & .14 & * & 4.2 & .57 \\
\hline 12 & 6.2 & .4 & 21 & 6.5 & 7 & .77 & * & .22 & .06 & .96 & .54 & .74 \\
\hline 14 & 17 & .4 & 72 & 17 & 13 & -- & * & .42 & .08 & 4.2 & .55 & 1.7 \\
\hline 17 & 18 & .5 & 74 & 21 & 21 & 1.3 & * & .29 & .06 & 1.6 & .80 & .50 \\
\hline 20 & 73 & 5.2 & -- & 48 & 41 & 6.6 & * & .91 & .26 & 2.2 & 2.1 & 1.2 \\
\hline 25 & 5 & .4 & -- & -- & -- & -- & * & .37 & .03 & -- & 3.0 & -- \\
\hline 30 & 19 & 2.8 & 22 & 22 & 4 & -- & * & .26 & .06 & -- & .16 & -- \\
\hline
\end{tabular}




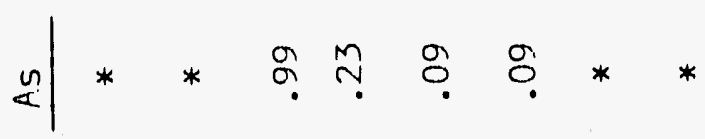

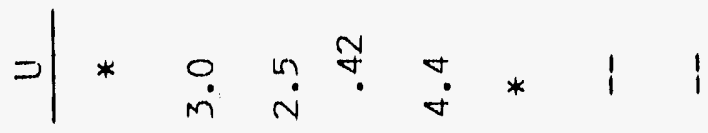

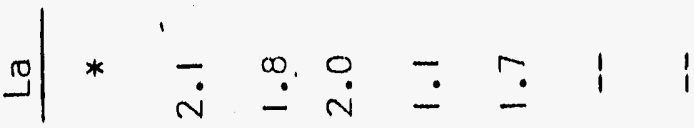

تี|

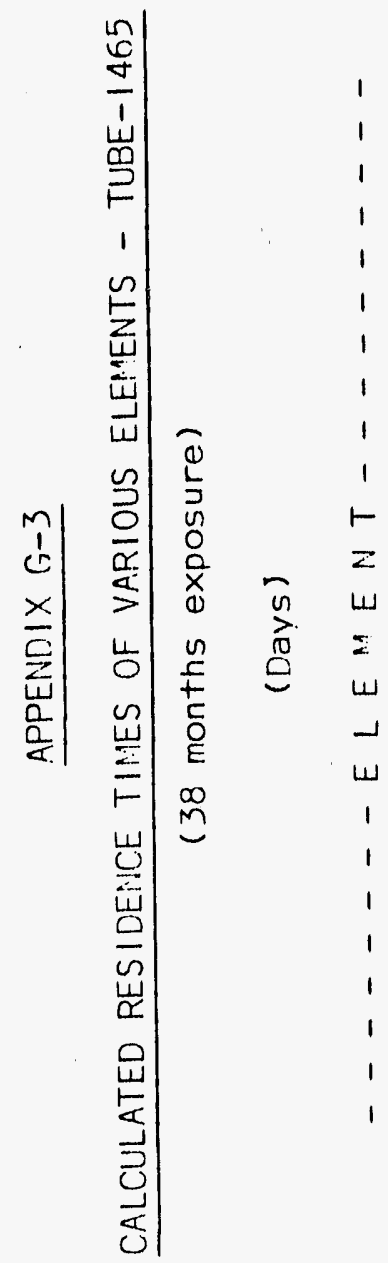

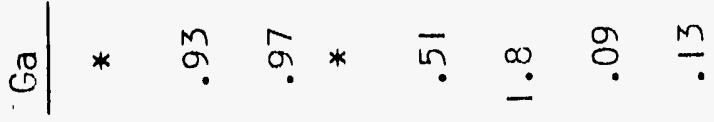

コ|*

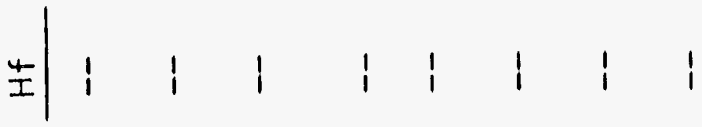

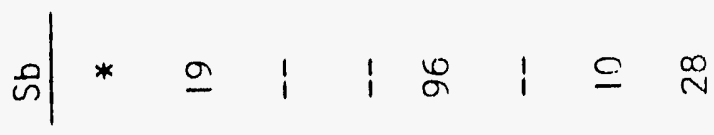

$\grave{N}|\stackrel{m}{i n} \underset{m}{\infty}=1 \bar{m}| 1 \mid$

స్

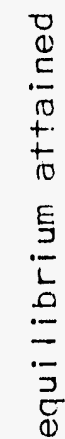

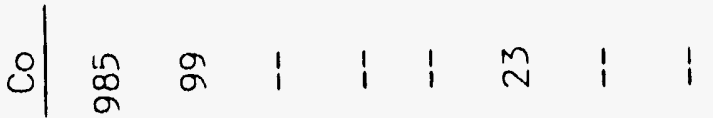

$\frac{1}{\geq}$

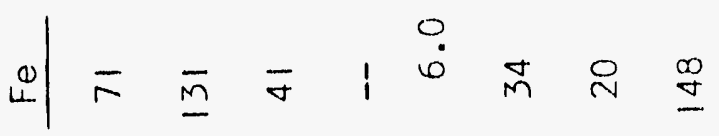

:

し)

ơ

Un

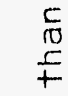

$\frac{1}{0}$
+
10
0
0
0

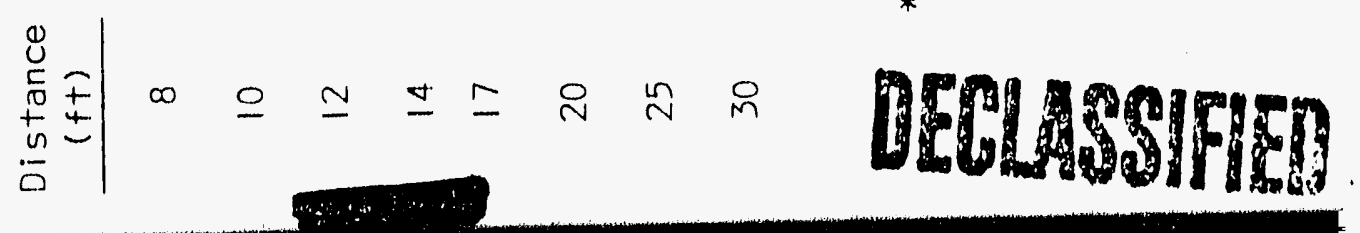


APPENDIX $C-4$

CALCULATED RESIDENCE TIMES FUEL COLU"N - 1166 A

( 7 days exposure)

(Days)

\begin{tabular}{|c|c|c|c|c|c|c|c|c|c|c|c|c|c|c|c|c|}
\hline Sample & & $\begin{array}{c}\text { Distance } \\
(\mathrm{ft})\end{array}$ & Sc & $\mathrm{Cr}$ & $\mathrm{Fe}$ & Co & $2 n$ & $\mathrm{Zr}$ & Sb & Hff & $\mathrm{Cu}$ & Ga & As & $\mathrm{La}$ & Eu & U \\
\hline \multirow[t]{8}{*}{ Element } & $\$ 1$ & 9.8 & .5 & 1.2 & 1.4 & 2.1 & 1.5 & 1.1 & 1.7 & .9 & .4 & $*$ & 1.8 & .4 & .04 & .7 \\
\hline & $\# 4$ & 12 & .4 & .6 & 1.5 & 2.8 & 1.3 & .9 & 1.3 & .5 & .9 & .5 & 1.6 & .9 & .09 & * \\
\hline & $\# 8$ & 15 & .5 & .9 & 2.6 & 3.1 & 1.8 & .9 & 4.6 & - & * & * & 1.6 & 2.6 & .21 & * \\
\hline & $\# 12$ & 18 & .5 & 1.4 & 2.5 & 3.1 & 1.7 & .5 & 3.2 & 1.6 & * & * & .9 & 1.8 & .13 & * \\
\hline & $\$ 17$ & 21.6 & .6 & 1.3 & 1.3 & 3.9 & 1.4 & 1.5 & 3.5 & 1.1 & .5 & * & 2.5 & 4.3 & .13 & * \\
\hline & $\$ 22$ & 25.3 & .7 & .6 & .2 & 2.0 & .4 & .5 & .7 & .7 & .1 & * & .3 & 1.1 & .02 & .5 \\
\hline & $\# 27$ & 29 & 1.3 & 1.1 & .5 & 3.0 & .6 & 1.9 & 4.0 & .4 & .4 & * & .2 & 2.1 & .64 & * \\
\hline & $\$ 34$ & 32.7 & .4 & 3.6 & 6.8 & - & 3.3 & 1.7 & $(16)$ & 3.2 & * & * & .4 & * & .88 & * \\
\hline
\end{tabular}

* Greater than 90\% of radioactive equilibrium attained

( ) Not included in average 
J * *

تี|

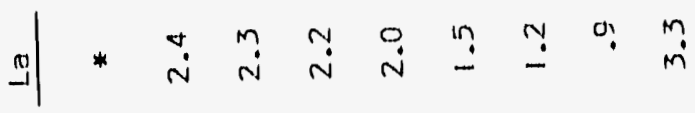

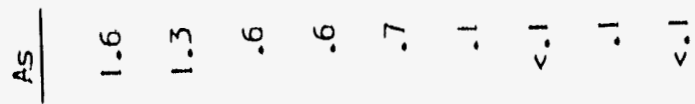

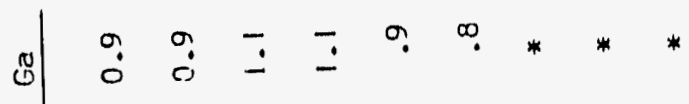

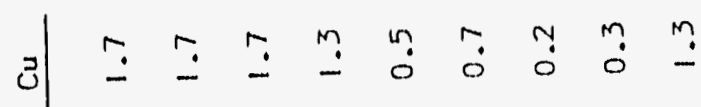

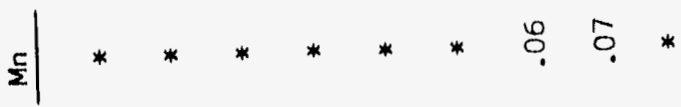

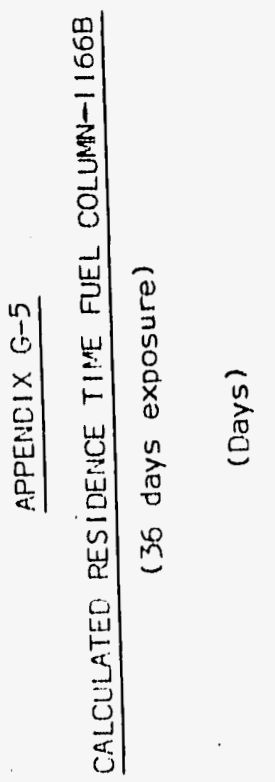

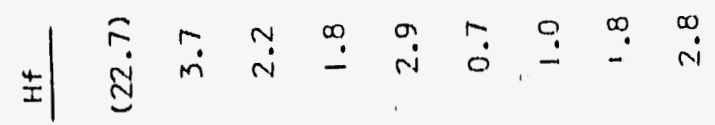

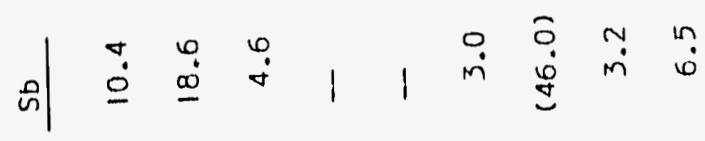

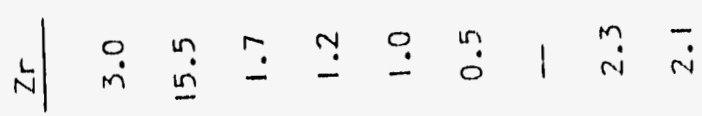

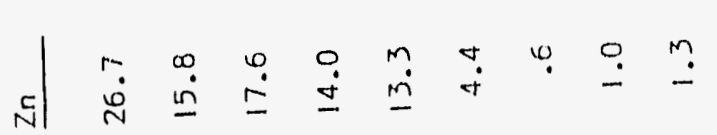

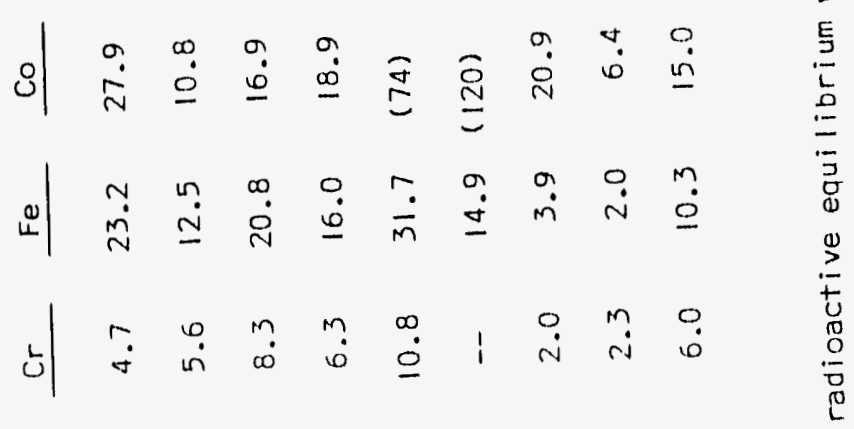

un|

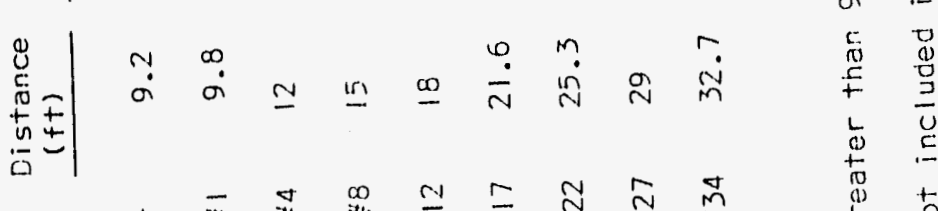

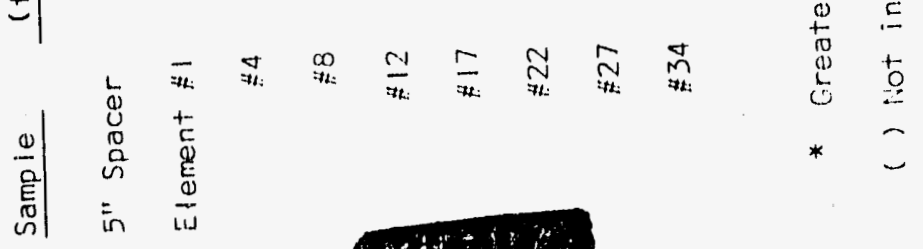




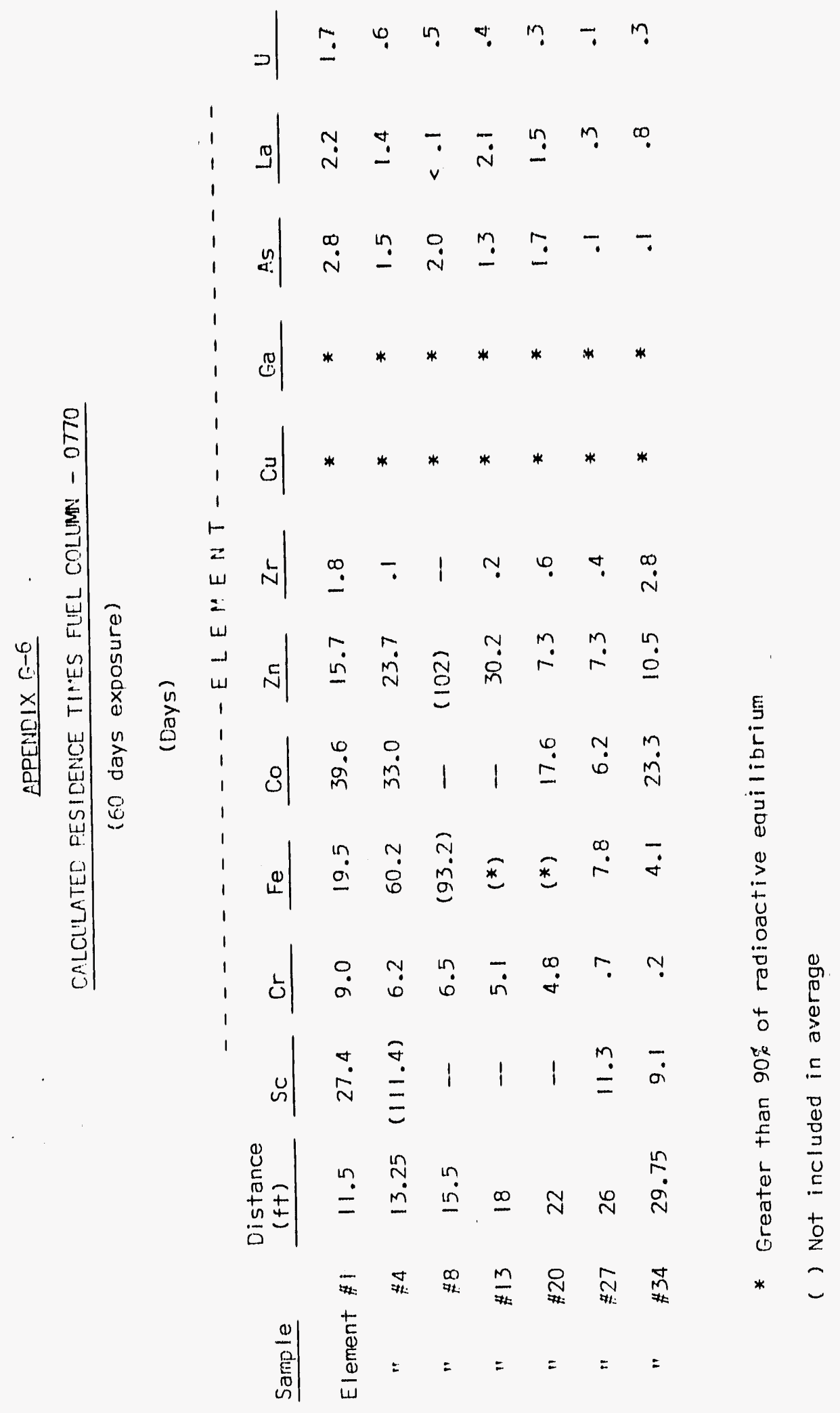



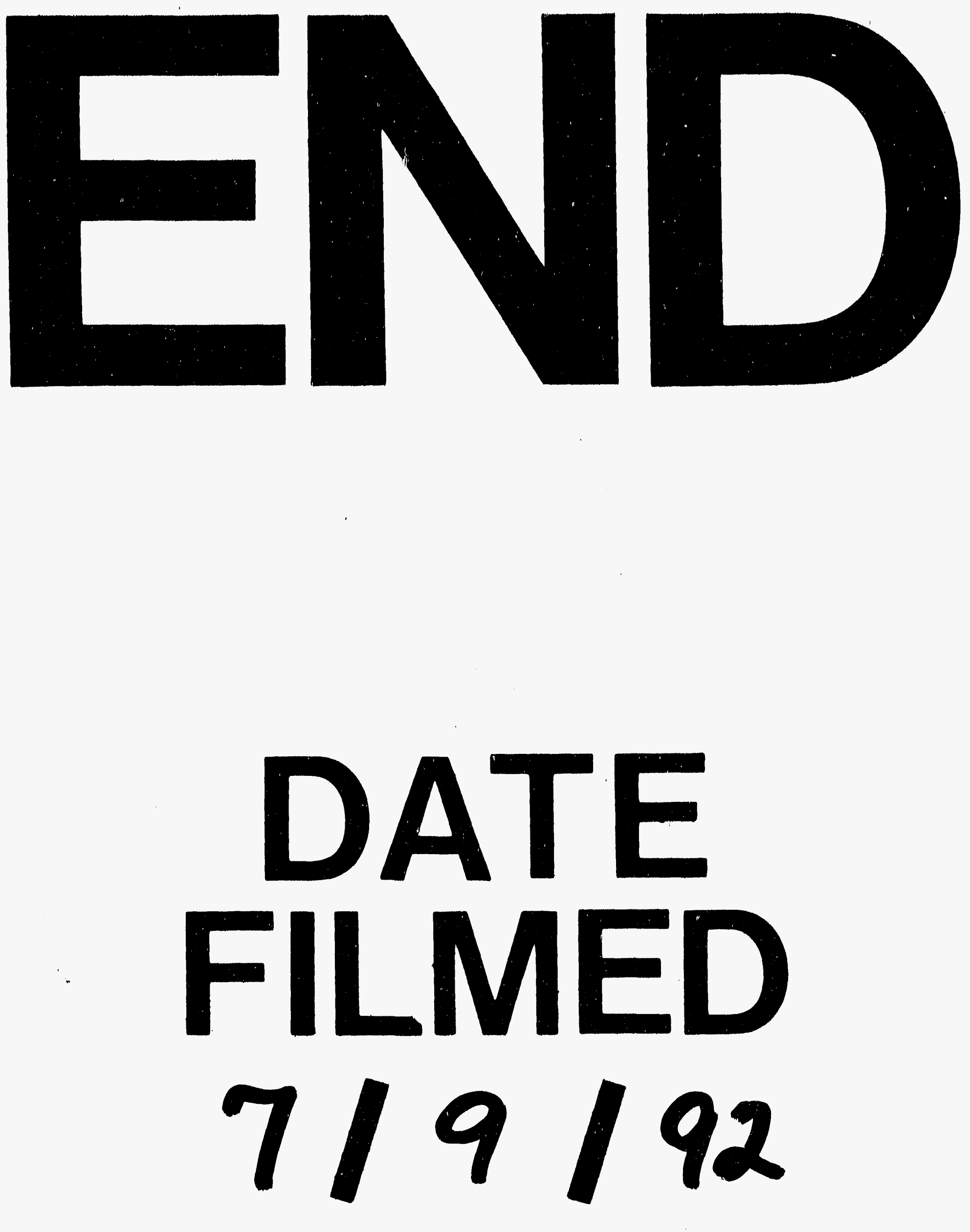
